\title{
Review
}

\section{Heterodimeric IL-15 in Cancer Immunotherapy}

\author{
Cristina Bergamaschi ${ }^{1}\left(\mathbb{D}\right.$, Vasiliki Stravokefalou ${ }^{2}$, Dimitris Stellas ${ }^{2}{ }^{-}$, Sevasti Karaliota ${ }^{2,3}$, Barbara K. Felber ${ }^{1}$ \\ and George N. Pavlakis ${ }^{2, *}$
}

1 Human Retrovirus Pathogenesis Section, Vaccine Branch, Center for Cancer Research, National Cancer Institute at Frederick, Frederick, MD 21702-1201, USA; cristina.bergamaschi@nih.gov (C.B.); barbara.felber@nih.gov (B.K.F.)

2 Human Retrovirus Section, Vaccine Branch, Center for Cancer Research, National Cancer Institute at Frederick, Frederick, MD 21702-1201, USA; vasiliki.stravokefalou@nih.gov (V.S.); dimitrios.stellas@nih.gov (D.S.); sevasti.karaliota@nih.gov (S.K.)

3 Basic Science Program, Frederick National Laboratory for Cancer Research, Frederick, MD 21702-1201, USA

* Correspondence: george.pavlakis@nih.gov

check for updates

Citation: Bergamaschi, C.; Stravokefalou, V.; Stellas, D.; Karaliota, S.; Felber, B.K.; Pavlakis, G.N. Heterodimeric IL-15 in Cancer Immunotherapy. Cancers 2021, 13 , 837. https://doi.org/10.3390/ cancers 13040837

Academic Editor: Leonidas

C. Platanias

Received: 15 January 2021

Accepted: 10 February 2021

Published: 17 February 2021

Publisher's Note: MDPI stays neutral with regard to jurisdictional claims in published maps and institutional affiliations.

Copyright: (c) 2021 by the authors. Licensee MDPI, Basel, Switzerland. This article is an open access article distributed under the terms and conditions of the Creative Commons Attribution (CC BY) license (https:// creativecommons.org/licenses/by/ $4.0 /)$.
Simple Summary: The rapidly expanding field of cancer immunotherapy uses diverse technologies, including cytokines, $\mathrm{T}$ cells, and antibody administration, with the aim to induce effective immune responses leading to tumor control. Interleukin-15 (IL-15), a cytokine discovered in 1994, supports the homeostasis of cytotoxic immune cells and shows promise as an anti-tumor agent. Many studies have elucidated IL-15 synthesis, regulation and biological function and explored its therapeutic efficacy in preclinical cancer models. Escherichia coli-derived single-chain IL-15 was tested in the first in-human trial in cancer patients. Its effects were limited by the biology of IL-15, which in vivo comprises a complex of the IL-15 chain with the IL-15 receptor alpha (IL-15R $\alpha$ ) chain, together forming the IL-15 heterodimer (hetIL-15). Currently, single-chain IL-15 and several heterodimeric IL-15:IL-15R $\alpha$ variants (hetIL-15, N-803 and RLI) are being tested in clinical trials. This review presents a summary of contemporary preclinical and clinical research on IL-15.

Abstract: Immunotherapy has emerged as a valuable strategy for the treatment of many cancer types. Interleukin-15 (IL-15) promotes the growth and function of cytotoxic CD8 ${ }^{+} \mathrm{T}$ and natural killer (NK) cells. It also enhances leukocyte trafficking and stimulates tumor-infiltrating lymphocytes expansion and activity. Bioactive IL-15 is produced in the body as a heterodimeric cytokine, comprising the IL-15 and the so-called IL-15 receptor alpha chain that are together termed "heterodimeric IL-15" (hetIL-15). hetIL-15, closely resembling the natural form of the cytokine produced in vivo, and IL-15:IL-15R $\alpha$ complex variants, such as hetIL-15Fc, N-803 and RLI, are the currently available IL-15 agents. These molecules have showed favorable pharmacokinetics and biological function in vivo in comparison to single-chain recombinant IL-15. Preclinical animal studies have supported their anti-tumor activity, suggesting IL-15 as a general method to convert "cold" tumors into "hot", by promoting tumor lymphocyte infiltration. In clinical trials, IL-15-based therapies are overall welltolerated and result in the expansion and activation of $\mathrm{NK}$ and memory $\mathrm{CD} 8^{+} \mathrm{T}$ cells. Combinations with other immunotherapies are being investigated to improve the anti-tumor efficacy of IL-15 agents in the clinic.

Keywords: cytokine; IL-15; IL-15 receptor alpha (IL-15R $\alpha$ ); heterodimeric IL-15 (hetIL-15); cancer immunotherapy; cytotoxic cells; clinical trials

\section{Introduction}

Interleukin-15 (IL-15) belongs to the $\gamma$-chain family of cytokines, that includes also IL-2, IL-4, IL-7, IL-9 and IL-21. These cytokines bind to the same $\gamma$-chain in their receptor complex and have unique and overlapping roles in regulating the development, maintenance, trafficking, and function of different lymphocyte subsets [1-5]. IL-15 is a growth, 
mobilization, and activation factor for many leukocyte populations, including natural killer (NK) cells, canonical $\alpha \beta \mathrm{TCR}^{+} \mathrm{CD}^{+}, \gamma \delta \mathrm{TCR}^{+}$, natural killer-T (NK-T), and intraepithelial T lymphocytes [1,6-8]. The non-redundant role of IL-15 in stimulating the cytotoxic activity of immune cells has supported the clinical development of IL-15 for cancer immunotherapy.

IL-15 was discovered as a molecule highly related to interleukin-2 (IL-2), which reached the clinical setting as an approved biological drug in 1992 and was the first paradigm of successful immunotherapy of cancer $[9,10]$. IL-15 and IL-2 share the same IL-2 receptor $\beta / \gamma$ dimer [11], but their systemic biological effects are different, as shown by studies performed using knockout (KO) mice. Lack of IL-2 causes immune activation and severe autoimmunity [12-15], whereas lack of IL-15 results in almost complete absence of NK cells and a severe reduction in peripheral $\mathrm{CD} 8^{+} \mathrm{T}$ lymphocytes [16]. The biological differences between IL-2 and IL-15 are determined by their different production sites $[1,2,17,18]$, their strength of association with the specific membrane binding proteins IL-2 receptor alpha (IL-2R $\alpha$ ) and IL-15 receptor alpha (IL-15R $\alpha$ ) [19], respectively, and the regulation of these molecules. IL-15 is not produced by lymphocytes; instead, it is produced from myeloid cells, stroma cells of many organs, and blood endothelial cells. Unlike IL-2R $\alpha$, the specific IL-15 binding protein named IL-15R $\alpha$ does not serve a receptor function, but it has evolved to be the other half of the IL-15 cytokine. Indeed, the cytokine is produced and functions as a heterodimer of two polypeptide chains, IL-15 and IL-15R $\alpha$ [20], named heterodimeric IL-15 (hetIL-15). hetIL-15 has shown anticancer activity in many model systems and is presently in multiple clinical trials for cancer immunotherapy.

In this review, we present the latest knowledge about hetIL-15 synthesis and regulation, about the mechanisms of function of this cytokine on the immune system, and an overview of the clinical applications of hetIL-15 in cancer immunotherapy. A comprehensive understanding of the unique biology of the IL-15 heterodimeric cytokine will allow for more rational design of IL-15-related studies at all levels, from basic biology to clinical research.

\section{Regulation of Heterodimeric IL-15 Production: Trans-Presentation and Soluble hetIL-15}

IL-15 was identified by two independent groups in 1994 as a 14 to $15 \mathrm{kDa}$ T cell growth factor similar to IL-2 in the simian kidney epithelial cell line [21], and in the human T cell leukemia virus-1 cell line [22]. Nucleotide or protein comparison failed to show any similarities between IL-15 and IL-2, but crystal structure analysis revealed that IL-15 has a four helix "up-up-down-down" structure [23], like IL-2 and other member of the same superfamily of cytokines. IL-15 is conserved among species, and human IL-15 shows $96 \%$ sequence homology with simian IL-15 [21,24] and 72\% with mouse [25] and rat IL-15.

Production of IL-15 is tightly regulated. In addition to regulation at the transcriptional level, IL-15 expression is controlled at several post-transcriptional and post-translational steps, such as mRNA stability, the generation of alternative spliced isoforms, intracellular trafficking, and secretion [26,27].

IL-15 has been reported to have a unique mechanism of action in vivo among the common $\gamma$-chain cytokines. IL-15 signals through the common IL-2/IL-15 receptor $\beta / \gamma$ complex [11]. Both IL-2 and IL-15 use additional unique and evolutionarily related surface binding proteins responsible for the specificity of binding, which were named IL-2R $\alpha$ and IL-15R $\alpha$, respectively. IL-2R $\alpha$ displays a lower affinity for IL-2 $\left(\mathrm{K}_{\mathrm{d}} \sim 10^{-8} \mathrm{M}\right)$ in the absence of IL-2 receptor $\beta / \gamma$, and acts by becoming part of the receptor. IL-15R $\alpha$ has a high affinity for IL-15 $\left(\mathrm{K}_{\mathrm{d}} \sim 10^{-11} \mathrm{M}\right)$ [19]. Dubois et al. [28] showed that IL-15 acts on the surface of producing cells in complex with the membrane-anchored IL-15R $\alpha$ to engage the IL-2/IL-15 receptor $\beta / \gamma$ complex in nearby cells, a process termed trans-presentation. Furthermore, in physiological conditions, IL-15 and IL-15R $\alpha$ expression from the same cells is required in order to achieve biological activity; bone marrow from chimeric mice repopulated with a mixture of IL-15-/- and IL-15R $\alpha$-/- cells failed to generate memory CD8 ${ }^{+} \mathrm{T}$ cells and mature NK cells [29-31]. An additional observation was that IL-15 and IL-15R $\alpha$ genes present similarities in their promoter function and are co-transcribed in 
different cell types [19,28,32-34]. The molecular mechanism explaining these intriguing observations has been reported by our group and others [35,36]. At the cellular level, coexpressed IL-15 and IL-15R $\alpha$ rapidly associate in the endoplasmic reticulum (ER) to form a stable heterodimeric membrane-bound complex that is exported to the cell membrane, where it stimulates adjacent IL-15R $\beta / \gamma$-expressing cells [35,37]. In the absence of IL-15R $\alpha$, IL-15 is highly unstable and is rapidly degraded before secretion. On the cell membrane, the complex is released as a bioactive soluble heterodimeric cytokine upon proteolytic cleavage of IL-15R $\alpha$ (Figure 1). Indeed, the heterodimer of the IL-15 chain with the IL-15R $\alpha$ chain was found circulating in the plasma of mice and humans [20]. Overall, IL-15R $\alpha$ acts as a chaperone molecule, influencing the bioavailability of IL-15 and expanding IL-15 effects from autocrine or juxtacrine to paracrine or endocrine modes $[35,36]$. Therefore, IL-15R $\alpha$ is part of a heterodimeric IL-15 cytokine, rather than functioning as a cytokine receptor [35]. These results are in agreement with the reported ability of recombinant soluble IL-15R $\alpha$ to act as a potent agonist of IL-15 function in vivo [38,39], and support our conclusion that the functional cytokine in vivo is the heterodimer, named hetIL-15.

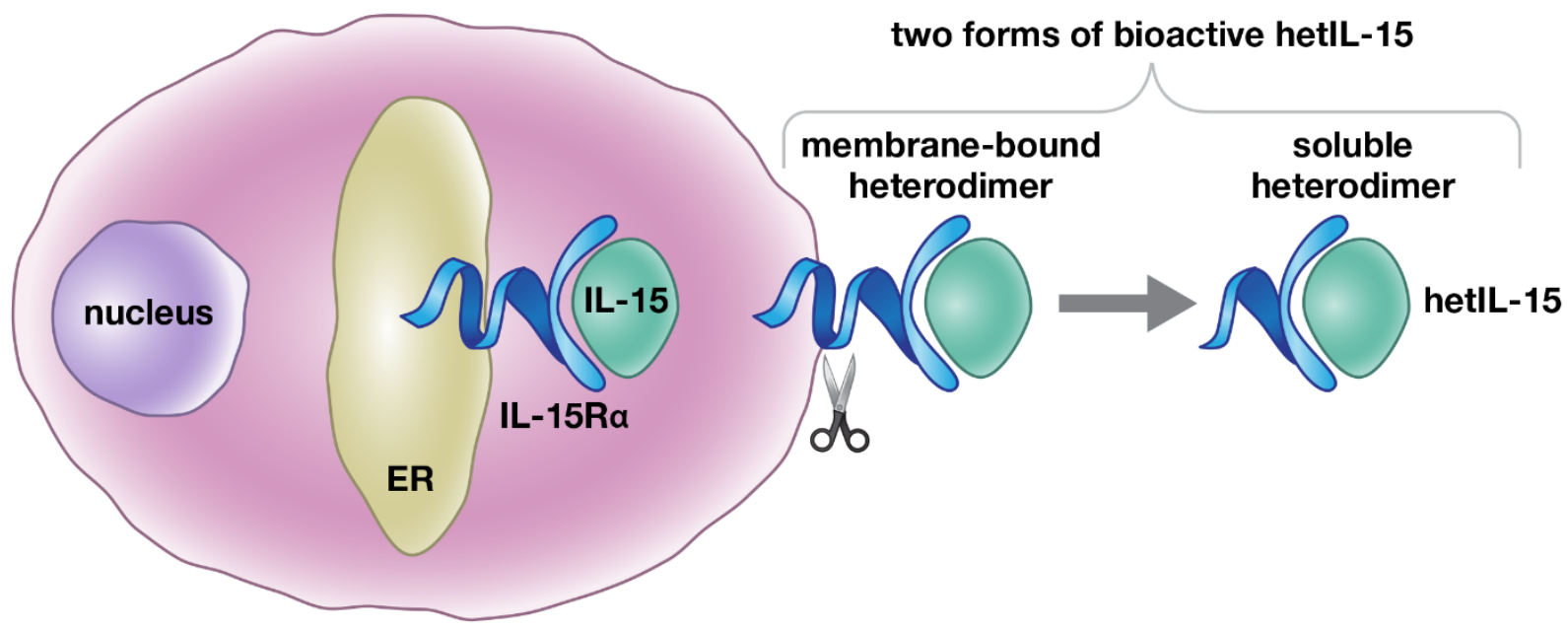

Figure 1. Schematic representation of hetIL-15 production. IL-15 is a heterodimeric cytokine, comprising the IL-15 and IL-15R $\alpha$ chains that are together termed heterodimeric IL-15 (hetIL-15). Simultaneous expression of IL-15R $\alpha$ in the same cells (dendritic cells, monocyte/macrophages, and others) is necessary for the production and secretion of IL-15 under physiological conditions. Upon co-expression, the two chains, IL-15 and IL-15R $\alpha$, associate in the endoplasmic reticulum (ER), due to their high binding affinity $\left(\mathrm{K}_{\mathrm{d}}=10^{-11} \mathrm{M}\right)$. The IL-15 heterodimer is then transported to the cell surface and released as a bioactive soluble heterodimeric molecule, upon proteolytic cleavage of IL-15R $\alpha$.

\section{Source and Physiological Function of hetIL-15}

hetIL-15 stimulates NK, NK-T, $\gamma \delta$ T, type-1 innate lymphoid cells (ILC1), memory and tissue resident $\mathrm{CD} 8^{+} \mathrm{T}$ cells [28-30,36,40-45], while having no strong effects on Tregs and inhibiting activation-induced Cell death (AICD).

IL-15 and IL-15R $\alpha$ mRNAs are widely and coordinately produced by several cell types, including monocytes, macrophages, dendritic cells, stroma cells from bone marrow and lymph nodes, blood endothelial and intestinal epithelial cells [46-48]. IL-15 reporter mouse models confirmed dendritic cells (DCs) and monocytes/macrophages as the primary source of IL-15 $[17,18]$. GFP reporter expression was found in CD8 ${ }^{+}$DCs in spleen and in both $\mathrm{CD}^{+}$and CD8 ${ }^{-}$DCs in lymph nodes. Expression of both IL-15 and IL-15R $\alpha$ can also be upregulated by several signals, including lipopolysaccharide (LPS), type-I interferons, and pathogen-associated molecular patterns (PAMPs), such as double-stranded RNA. In contrast to the widespread expression of IL-15 and IL-15R $\alpha$, the cytokine receptor $\beta$ and $\gamma$ subunits are more selectively expressed by lymphocytes, with the highest level found on activated $\mathrm{NK}$ and $\mathrm{CD} 8^{+} \mathrm{T}$ cells. 
Trans-presentation of IL-15 and shedding of soluble hetIL-15 directly stimulates proliferation and survival in IL-15 responsive cells and regulates their biological functions [28]. The IL-15 trans-presentation mechanism applies to $\mathrm{CD} 8^{+}, \gamma \delta \mathrm{T}$ cells and NK cells [28-30,36,40-45,49]. In responsive cells, hetIL-15 signaling results in the activation of JAK1 and JAK3 kinases that promote the phosphorylation and dimerization of signal transducer and activator of transcription protein-3 and 5 (STAT3/5). STAT dimers traffic to the nucleus to function as transcriptional factors. Additional pathways activated by hetIL-15 include the PI3K/Akt/mTOR and the RAS/RAF MAPK pathways. Overall, these signaling pathways enhance the expression of genes involved in proliferation and anti-apoptotic signals such as Bcl-2, c-Myc, c-Fos, c-Jun, Mcl-1, Bcl- $x l$, in aerobic glycolysis, and in effector and cytotoxic immune cell functions and migration, such as IFN- $\gamma, T N F-\alpha$, XCL1, Granzyme and Perforin. hetIL-15 effects on the immune system and the selectivity of hetIL-15 responsiveness makes this cytokine attractive for cancer immunotherapy.

\section{IL-15:IL-15R $\alpha$ Complexes as Cytokine Agonists in Animal Models and Their Efficacy in Preclinical Cancer Studies}

Immunotherapy is a promising intervention against cancer. Optimized immunotherapeutic strategies need to be implemented to convert the inefficient immune responses commonly found in the tumor environment to effective responses leading to prolonged tumor control. The presence of tumor-infiltrating T cells (TILs) is considered to be one of the most important biomarkers to predict the clinical benefit in response to immunotherapies [50-52]. Several studies highlighted the potential anti-cancer efficacy of IL-15-based therapies.

Single chain recombinant human IL-15 (sch rhIL-15), hetIL-15, and several IL-15:IL$15 \mathrm{R} \alpha$ fusion proteins (Figure 2) have been produced and tested in preclinical models (mice and monkeys) to determine the pharmacokinetics, the bioavailability and the bioactivity of these agents, in order to advance to clinical trials for cancer immunotherapy. sch rhIL-15, hetIL-15, and IL-15:IL-15R $\alpha$ fusion agonists were also all shown to have anti-cancer activity in several mouse tumor models.

\section{hetIL-15/ NIZ985}

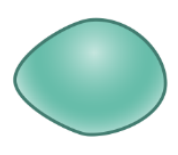

\section{hetIL-15FC}

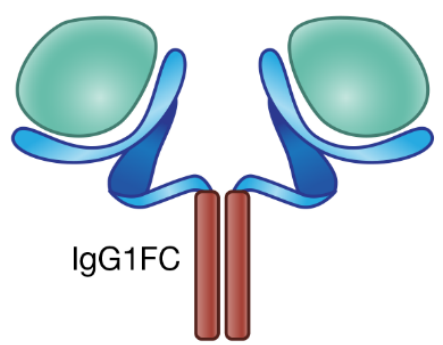

N-803 (Anktiva)/ ALT-803

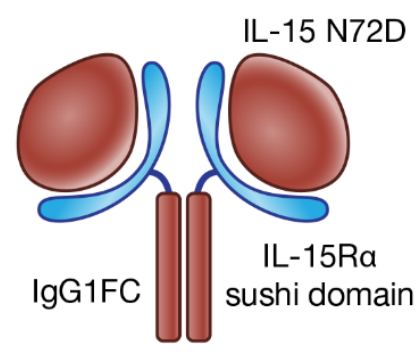

RLI

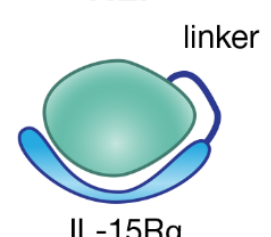

IL-15Ra sushi domain

Figure 2. Different IL-15 preparations used in cancer immunotherapy. The single-chain E. coli-derived IL-15 (sch rhIL-15, left) [53] is the first IL-15 tested in the clinic, but its use is limited by the short half-life and potential toxicity. The natural form of IL-15 produced physiologically is the heterodimer of IL-15 with IL-15R $\alpha$. Several heterodimeric forms have been developed. From left to right, human embryonic kidney 293 (HEK293)-derived or Chinese hamster ovary (CHO)-derived hetIL-15/NIZ985, the soluble heterodimer of IL-15 with IL-15R $\alpha$, upon natural shedding of IL-15R $\alpha$ from the membrane of producing cells [54]; human HEK293-derived hetIL-15FC, a dimeric form in which soluble IL-15R $\alpha$ is fused to the Fc region of IgG1; N-803, also known as Anktiva and ALT-803, consisting of a CHO-derived soluble complex comprising mutated IL-15 (IL-15 N72D) and a dimeric IL-15R $\alpha$ sushi domain-IgG1 Fc fusion protein [55]; Receptor-Linker-IL-15 (RLI) consists of the IL-15R $\alpha$ sushi domain fused to IL-15, via a 20-amino acid flexible linker [56].

\section{1. sch rhIL-15}

sch rhIL-15 is a non-glycosylated monomer of $\sim 12 \mathrm{kDa}$ produced in E. coli [53]. It has been tested in preclinical studies upon intravenous (IV) [57], subcutaneous (SC) [58], and continuous intravenous infusion (CIV) [58]. sch rhIL-15 administration in macaques 
increased the frequency of cycling peripheral NK and effector memory CD8 ${ }^{+} \mathrm{T}$ cells [57], as well as promoting cell growth and tissue migration of $\mathrm{CD} 4^{+}$effector memory $\mathrm{T}$ cells [59]. Although sch rhIL-15 treatment was overall well-tolerated, some toxicity was observed, including hypotension, fever, chills, and rigors. At higher doses, a transient drop in circulating neutrophils was observed, alongside the accumulation of granulocytes in the liver [60].

Several studies in mice have demonstrated that sch rhIL-15 monotherapy results in tumor growth control, decreased metastatic burden, and increased survival in preclinical models of melanoma, colon and prostate carcinoma and lymphoma. The anti-cancer effect of sch rhIL-15 depended on the systemic activation of NK and $\mathrm{CD}^{+} \mathrm{T}$ cells and the maintenance of specific anti-tumor T cells [61-67].

\section{2. hetIL-15 (NIZ985)}

IL-15 is generated as a heterodimeric complex of IL-15 and IL-15R $\alpha$ molecules in both physiologic and pathologic conditions [20]. Our group has previously reported a systematic approach to reproduce all the natural steps of production and processing of hetIL-15 in engineered human cells. We generated stable, clonal HEK293-derived human cell lines that secrete high levels of glycosylated hetIL-15 cytokine $[54,68]$. The human hetIL-15 has been licensed by Novartis, and the clinical trials continue under the name NIZ985. Upon administration in mice, hetIL-15 was characterized by an extended half-life and promoted a robust expansion of NK and T cells, demonstrating pharmacokinetics and in vivo bioactivity superior to sch rhIL-15 [35,54]. Pharmacokinetics, pharmacodynamic and toxicity profile of hetIL-15 were also evaluated in macaques [69]. hetIL-15 was provided via SC route at the dose of $0.5,5$ and $50 \mu \mathrm{g} / \mathrm{kg}$, three times/week for a two-week cycle, and resulted in persistent bioactive levels of plasma IL- 15 with $\mathrm{T}_{1 / 2}$ of $\sim 12 \mathrm{~h}$. Effects of the treatment included increased blood lymphocyte cell count and cytotoxic cells, proliferation of $\mathrm{T}$ cells, and elevated plasma IL-18 levels $[69,70]$. At the higher $50 \mu \mathrm{g} / \mathrm{kg}$ dose, edema was observed in various organs, including the lower abdomen, extremities, and genital area, and swelling was observed in lymph nodes, along with signs of capillary leak syndrome and kidney dysfunction. Body temperature was generally increased following dose administration [69]. The favorable properties of hetIL-15 allowed the development of delivery protocols that maximized effects while avoiding cytokine spikes, via SC delivery of increasing (doubling) doses of hetIL-15, ranging from 2 to $64 \mu \mathrm{g} / \mathrm{kg}$ in a two-week cycle [69]. Each hetIL-15 dose induces lymphocyte proliferation, which leads to more targets, requiring increasing levels of cytokine for efficient stimulation of the increased lymphocytes. Delivery of hetIL-15 following a doubling step-dose regimen provides sufficient cytokine to sustain the continuous expansion and activation of lymphocytes minimizing any side effects.

hetIL-15 therapy has been shown to be effective against both primary tumor and metastatic disease in the B16 melanoma, MC38 colon carcinoma, TC-1 carcinoma, breast, and pancreatic tumor mouse models [71,72] (also shown in our unpublished data). The mechanism of action involves potentiation of multiple pathways, including leukocyte expansion and trafficking to the tumor, increase in cell-cell interactions, anti-tumor cytokine production, and direct cytotoxicity. In the tumor, hetIL-15-stimulated $\mathrm{NK}, \mathrm{CD}^{+}$and $\mathrm{CD} 4^{+}$ T cells show increased proliferation, survival, and cytotoxic commitment, with high levels of IFN- $\gamma$ and granzyme B secretion. hetIL-15 treatment causes activated lymphocytes to produce the Chemokine (C motif) ligand 1 (XCL1) that recruits conventional type-1 dendritic cells ( $\mathrm{cDC} 1$ ) to the tumor. These $\mathrm{CDC} 1$ cells in turn secrete Chemokine (C-X-C motif) ligand 9 (CXCL9) and Chemokine (C-X-C motif) ligand 10 (CXCL10), two IFN- $\gamma$ driven chemokines, leading to the recruitment of CXCR3 ${ }^{+}$effector $\mathrm{NK}$ and $\mathrm{CD} 8^{+} \mathrm{T}$ cells, that may further produce IFN- $\gamma$ and generate anti-tumor inflammatory responses in a self-amplifying positive feedback loop (Figure 3) [71]. These data are in agreement with one study demonstrating the role of endogenous IL-15 in inducing higher densities of immune cells at the centers and invasive margins of tumors that correlate with better disease outcomes and increased survival in patients with colorectal cancers [73]. 


\section{Control}

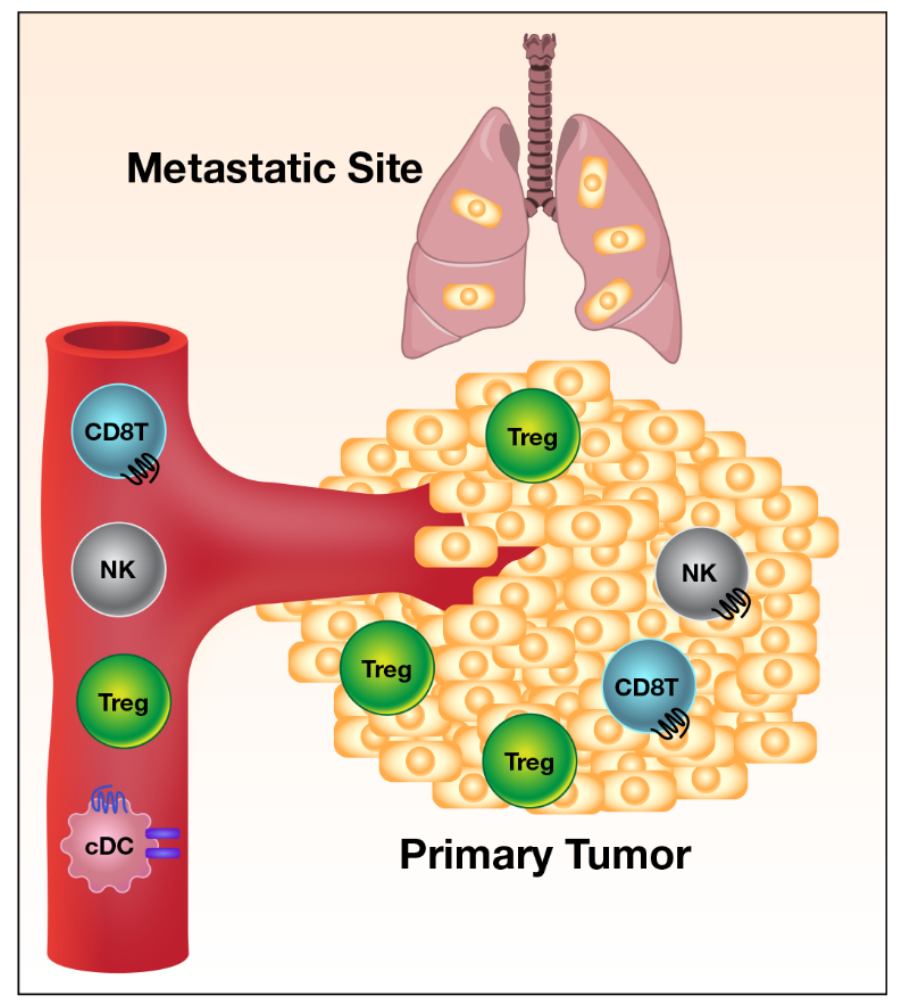

hetIL-15

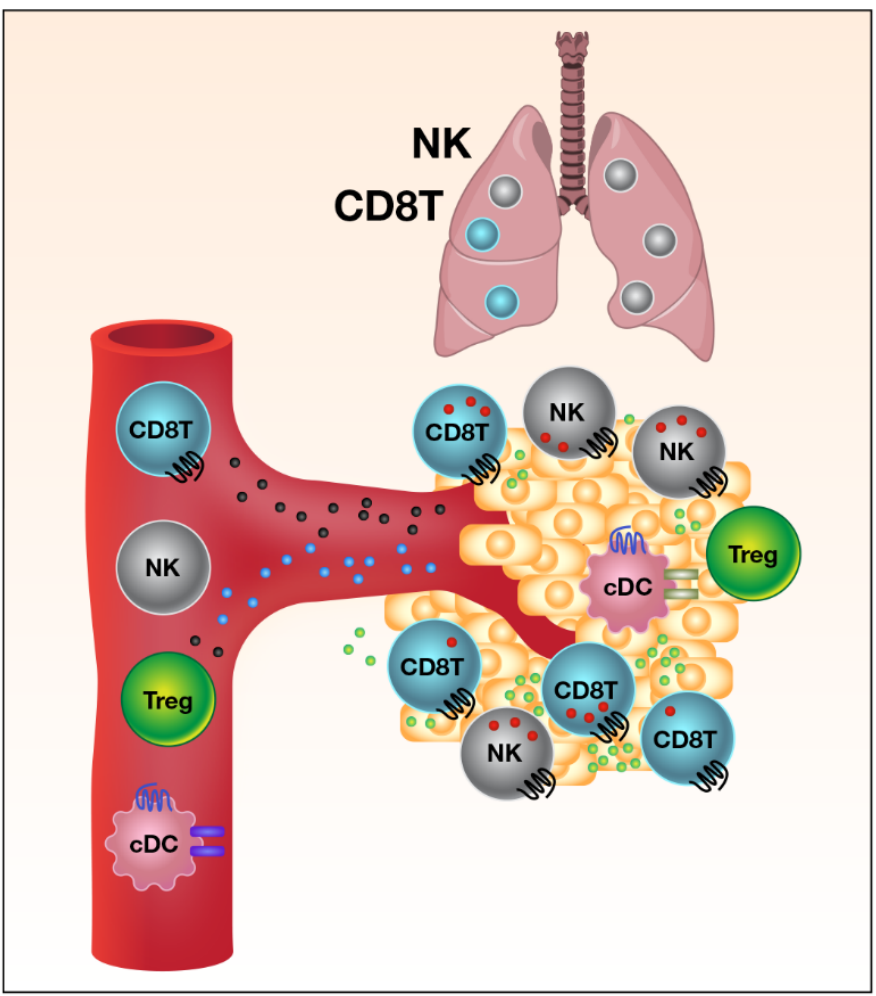

\section{IFN- $\gamma \quad$ XCL1 $\bigcirc$ CXCL9/10 Granzyme B/Perforin IFN- $\mathrm{R}$ OND xCR1 OOM CXCR3}

Figure 3. Mechanism of anti-tumor activity of heterodimeric IL-15. hetIL-15 therapy is beneficial against both primary tumor and metastatic disease. Use of hetIL-15 is a general method to push effector lymphocytes inside the tumor. IL-15 directly stimulates the cytotoxicity (granzyme B, red dots) and IFN- $\gamma$ production (green dots) of CD8 ${ }^{+} \mathrm{T}$ and $\mathrm{NK}$ cells in the tumor microenvironment. IL-15 also induces the secretion of XCL1 (blue dots) from activated lymphocytes, a chemokine responsible for the recruitment of $X C R 1^{+}$conventional dendritic cells (cDC) with cross-priming ability. cDC within the tumor support $C D 8^{+} \mathrm{T}$ cells effector function and secretes Chemokine (C-X-C motif) ligand 9 (CXCL9) and Chemokine (C-X-C motif) ligand 10 (CXCL10) (black dots) in response to IFN- $\gamma$. CXCL9 and CXCL10 create a gradient that attracts more $\mathrm{CXCR}^{+}$effector $\mathrm{CD}^{+} \mathrm{T}$ and NK cells. As a result, the number of $\mathrm{CD} 8^{+} \mathrm{T}$ and NK cells, as well as the CD8/Treg ratio, increase in hetIL-15-treated tumors, leading to tumor growth control.

\section{3. hetIL-15Fc}

An additional form of fully glycosylated hetIL-15 in which the C-terminus of soluble IL-15R $\alpha$ is fused to the Fc region of human IgG1 has been generated and named hetIL-15Fc. In mouse models, hetIL-15Fc was shown to be superior to sch rhIL-15 and to possess antitumor activity by several investigators [38,39,74-77]. hetIL-15Fc was characterized by an increased serum half-life and induced a strong expansion of both $\mathrm{NK}$ and memory $\mathrm{CD}^{+} \mathrm{T}$ cells that was 50-fold more potent than sch rhIL-15. The fusion to the Fc region may provide the ability to act as a cell-associated cytokine, mimicking the IL-15 trans-presentation, upon in vivo delivery of the cytokine.

\subsection{N-803 (Anktiva, Formerly ALT-803)}

N-803 consists of a novel IL-15 mutant (N72D) bound to the extracellular region of IL$15 R \alpha$ fused to IgG1 Fc. It was suggested that the N72D mutation in IL-15 confers a five-fold increase in its biological activity as compared to single-chain wild type IL-15, by enhancing binding to CD122 and CD122/CD132 activation [78]. It is not clear what is the role of N72D 
mutation on the biological activity of the heterodimeric form. This part of the molecule is prone to deamidation, and it was suggested that production as a heterodimer and N79-glycosylation partially prevents N77-deamidation [68]. The safety, pharmacokinetics, and immunological effects of N-803 have been assessed both in mice [55,79-81] and in cynomolgus monkeys [81]. Upon delivery in mice, N-803 stimulated CD11b ${ }^{+}$CD27 ${ }^{\text {hi }}$ NK cells and memory $\mathrm{CD} 122^{+} \mathrm{CD} 44^{+} \mathrm{T}$ cells and exhibited a 35-fold longer serum half-life than sch rhIL-15 [79,81]. Cynomolgus monkeys showed a dose-dependent increase in blood lymphocytes along with mild multifocal lymphocytic infiltration in multiple organs after weekly IV administration of N-803 at 30 and $100 \mu \mathrm{g} / \mathrm{Kg}$. Administration of N-803 was not accompanied by increased plasma level of inflammatory cytokines IFN- $\gamma$, TNF- $\alpha$, IL- 6 , IL-5, IL-4, or IL-2. Pharmacokinetic analysis estimated the $\mathrm{T}_{1 / 2}$ of N-803 to be $7.2-8 \mathrm{~h}$. Overall, N-803 showed a wide therapeutic window with no toxicity in vivo [81].

N-803 treatment proved effective in reducing tumor growth and/or in improving survival in several mouse cancer models, including multiple myeloma [82], breast cancer [79], melanoma [79,81], glioblastoma [83], colon carcinoma [79,81], ovarian cancer [84] and lymphoma [85]. As an anti-cancer agent, $\mathrm{N}-803$ promoted the migration of $\mathrm{CD} 8^{+} \mathrm{T}$ and NK cells within the tumor bed and sustained their cytotoxicity and ability to secrete IFN- $\gamma$.

\subsection{RLI (Receptor-Linker-IL-15) Superagonist}

The N-terminus region (1-66 aa) of the mature IL-15R $\alpha$, called the sushi domain, contains all the structural amino acids responsible for IL-15 binding at high affinity [23]. Additionally, the IL-15R $\alpha$ sushi domain alone also functions as a potent agonist of IL-15 action [56]. The protein called Receptor-Linker-IL-15 (RLI) consists of the IL-15R $\alpha$ sushi domain fused to IL-15, via a 20-amino acid flexible linker, and it was shown to act as an IL-15 agonist in vivo. Delivery of RLI to mice resulted in prolonged plasma IL-15 levels and bioactivity similar to hetIL-15Fc complexes [56]. RLI also greatly enhanced the reconstitution of human $\mathrm{NK}$ and $\mathrm{CD}^{+} \mathrm{T}$ cells in humanized mice, via the strong upregulation of genes involved in cellular activation and survival: CD69, Bcl-2 and Bcl-xl [43].

RLI demonstrated strong anti-tumor effects and improved survival in the B16 melanoma model. RLI was shown to reduce primary tumor growth and metastatic burden of human colon carcinoma in an orthotopic nude mouse, through the stimulation of NK cells in absence of T cells [86]. Anti-metastatic effects were also observed in the 4T1 breast cancer model [87].

\subsection{Optimized DNAs Expressing hetIL-15}

The induction of bioactive systemic levels of hetIL-15 has been greatly facilitated by improvements in DNA vector design and delivery methods.

Intramuscular administration of such DNAs delivered by in vivo electroporation resulted in systemic levels of bioactive IL-15 in macaques, accompanied by expansion of NK, $\gamma \delta \mathrm{TCR}^{+}$and memory CD8 ${ }^{+} \mathrm{T}$ cells [88]. This study demonstrated that the injection of hetIL15-expressing DNAs or hetIL-15 purified protein produced similar results. Muscles are a physiologic location for IL-15 production [89-91], and the repeated transient expression of hetIL-15 did not cause any adverse effects in macaques.

Overall, the anti-tumor efficacy of IL-15-based therapies depends on changes in the cellular and cytokine landscape within the tumor. IL-15 is proposed as a general method to enhance leukocyte (such as T, NK cells and cross-priming DCs) entry into tumors, as well as their function, increasing the success rate of immunotherapeutic interventions.

For clinical applications, the advantages of the IL-15:IL-15R $\alpha$ heterodimeric forms in comparison to sch rhIL-15 are: (i) easier production and higher yield of glycosylated forms; (ii) increased stability in vivo; and (iii) increased bioactivity on a molar basis, thereby offering a simpler delivery mechanism and dosing structure. These properties result in a reduced risk of toxicity related to cytokine spikes, making the IL-15:IL-15R $\alpha$ complex the most favorable form for cancer immunotherapy in humans. 


\section{IL-15 in Combination Therapy for Cancer}

The cancer immunotherapy field currently focuses on combining the use of IL-15 with other agents, i.e., checkpoint inhibitors, monoclonal antibodies, chemotherapy, radiation, and chimeric antigen receptor T (CAR-T) cells, in order to target multiple mechanisms and enhance the immune response against tumors. Indeed, the inability of tumor-infiltrating lymphocytes (TILs) to eradicate cancer could be attributed to many factors, such as their functional impairment, secondary to suppression induced by Tregs and other immunesuppression mechanisms, the lack of proper co-stimulation, or Major Histocompatibility Complex (MHC) down-regulation on the target cancer cells, resulting in evasion from immune recognition. The effectiveness of TILs may be limited by a multitude of negative regulatory mechanisms, including anti-inflammatory cytokines (such as IL-10 [92] and TGF$\beta$ [93]), inhibitory cells (e.g., Tregs [94] and myeloid-derived suppressor cells [95]), and the up-regulation of inhibitory receptors, such as programmed death-1 (PD-1), and its ligands, programmed death-ligand 1 and 2 (PD-L1 and PD-L2), which have been demonstrated to attenuate immune responses in the context of tumor immunity [96]. Several mechanisms of cancer resistance to therapies are also reviewed in Visconti et al. [97].

\subsection{Combination of IL-15 with Checkpoint Inhibitors and Monoclonal Antibodies}

Several interventions combining IL-15 agents with checkpoint inhibitors, antibodies stimulating immune cell functions (e.g., anti-CD40, anti-CD16), monoclonal antibodies specific for tumor-associated antigens, and immunotoxins have been tested in preclinical models, with promising results.

IL-15 induces the expression of the immune checkpoint molecules PD-1, T-cell Immunoglobulin domain and Mucin domain 3 (TIM-3) and T-cell immunoreceptor with Ig and ITIM domain (TIGIT) on CD8 ${ }^{+} \mathrm{T}$ cells and promotes the secretion of the antiinflammatory cytokine IL-10 $[65,66]$. The combination of sch rhIL-15 with both anti-CTLA4 and anti-PD-L1 was tested in the CT26 and MC38 colon carcinoma and in the Transgenic Adenocarcinoma Mouse Prostate C2 (TRAMP-C2) cancer models in mice. Although the single agents only provided limited activity, the triple therapy resulted in significant antitumor benefit [65]. Similarly, combination of N-803 with checkpoint inhibitors promoted the development of long-term immune responses, further enhancing the anti-tumor efficacy of both single agents $[79,83]$. RLI also enhanced the anti-tumor activity of PD- 1 antagonist [98]. TIGIT has emerged as an additional checkpoint inhibitor for novel combinatorial therapy with IL-15 [99].

Additional anti-cancer effects were also observed when IL-15 was delivered together with anti-CD40 agonist antibodies in TRAMP-C2 prostatic tumor-bearing mice $[67,100]$. The combination therapy induced a 10-fold increase in the number of TRAMP-C2-specific $\mathrm{CD}^{+} \mathrm{T}$ cells, thus resulting in tumor growth control. Mechanistically, the stimulation via $\mathrm{CD} 40$ rescues $\mathrm{CD} 4^{+} \mathrm{T}$ cell helper activity, promoting the generation of tumor-specific $\mathrm{CD} 8^{+}$ $\mathrm{T}$ cells [101].

Due to the stimulatory effects on NK cells, IL-15 agents have been used in combination with anti-cancer monoclonal antibodies, resulting in increased antibody-dependent cell cytotoxicity (ADCC) and anti-tumor efficacy. Positive results were reported for the combination of sch rhIL-15 with cetuximab in breast cancer models [102,103], with rituximab against chronic lymphocytic leukemia (CLL) [104] and EL4 lymphoma transfected with human CD20 [105] and with alemtuzumab in a xenograft model of adult T cell lymphoma (ATL). Preclinical studies also supported the use of N-803 in combination with anti-CD20 monoclonal antibodies, to enhance NK cell function and ADCC against B cell lymphoma [85,106]. Advances also include the use of N-803 together with bi/tri-specific antibodies (BiKE and TriKE), to enhance the survival and expansion of NK cells in vivo. BiKE and TriKE work by creating an immunological synapse between tumor and NK cells. These molecules contain single-chain variable fragments (scFvs) against both CD16 activating receptors on NK cells and tumor associated antigen(s), such as CD19, CD20 and CD33, connected by human IL-15 [107-109]. Other receptors such as NKG2D and 2B4, 
when triggered in concert, have been shown to activate NK cells to a similar degree as engagement of CD16 alone. Fusion proteins comprising RLI have also been developed to further enhance anti-tumor effectiveness. A fusion protein of RLI with anti-GD2 antibody that targets the widely expressed tumor-associated antigen disialoganglioside displayed strong antitumor activities in the subcutaneous EL4 and metastatic NXS2 mouse models via enhanced ADCC [110]. Additionally, trifunctional fusion proteins composed of a tumor-specific recombinant antibody, RLI, and the extracellular region of co-stimulation molecules 4-1BBL, OX40L or glucocorticoid-induced TNF receptor ligand (GITRL), were effective in reducing lung metastasis in the B16-FAP melanoma mouse model, through the induction of T cell proliferation and cytotoxicity, and the secretion of IFN- $\gamma[111,112]$.

\subsection{Combination of IL-15 with Chemotherapy and Radiation}

Combination regimens of IL-15 with chemotherapy or radiation have also shown efficacy in mice. Both chemotherapy and radiation directly reduce tumor burden and support the development of tumor-specific immune responses through the release of tumor antigens from necrotic cells and by depleting immunosuppressive populations within the tumor microenvironment. Indeed, IL-15 administration potentiates the anti-cancer efficacy of cyclophosphamide [113,114], cisplatin [115], gemcitabine [116] and radiation [117]. Combination therapies of hetIL-15 with chemotherapy and surgical resection of primary tumors are currently under evaluation.

\subsection{Combination of IL-15 with Adoptive Cell Therapy}

Adoptive cell transfer (ACT) therapy is a promising strategy to fight cancer and consists of the administration of patient-derived TILs, T cells specific for tumor epitopes, or chimeric antigen receptor engineered T (CAR-T) or CAR-NK cells. The first anti-CD19 CAR-T cell therapy was approved by the FDA for hematological malignancies in 2017 [118]. ACT therapy effectiveness has been linked to both the phenotype of the transferred cells and their in vivo persistence. Beneficial effects of IL-15 in ACT immunotherapy protocols have been reported in animal models and are being explored in the clinic. IL-15 can be used for the ex vivo generation and expansion of tumor-specific lymphocytes, as well as for the in vivo support of the transferred cells.

Ex vivo pre-culture with IL-15 resulted in the generation of anti-tumor $\mathrm{CD} 8^{+} \mathrm{T}$ cells with the central memory phenotype. In comparison to IL-2, T cell clones generated in the presence of IL-15 displayed higher proliferative capability and cytokine secretion potential and were effective in causing tumor regression upon transfer in mice [61]. Similarly, in a macaque model, IL-15-stimulated Cytomegalovirus-specific CD8 autologous clones were characterized by a central memory rather than terminally differentiated effector phenotype and persisted in vivo for longer periods of time [119]. IL-15 was also reported to promote the in vitro expansion of human T cells with stem cell-like features [120]. These cells are multipotent, self-renewing, and capable of generating potent tumor-specific effector $\mathrm{T}$ cells upon transfer in vivo [121]. Indeed, CAR-T cells expanded ex vivo with IL-15 were characterized by a less-differentiated phenotype, with reduced expression of exhaustion and pro-apoptotic molecules, and by an improved mitochondrial metabolism [122].

The in vivo persistence of adoptively transferred cells benefits from lymphodepleting pre-conditioning of the host before cell infusion. It has been shown that hetIL-15 administration improved the outcome of ACT therapy in the absence of lymphodepletion in a B16 melanoma mouse model [72], establishing an efficient protocol of ACT. Treatment with hetIL-15 resulted in tumor infiltration and persistence of both adoptively transferred gp100specific Pmel- 1 cells and endogenous CD8 ${ }^{+} \mathrm{T}$ cells. Importantly, hetIL-15 treatment led to preferential tumor enrichment and increased cytotoxic ability of tumor-infiltrating Pmel-1 cells, resulting in improved tumor control and survival. Thus, hetIL-15 administration improves the outcome of ACT in immunocompetent hosts, a finding with significant implications for improving future cell-based cancer therapy strategies. These results may also provide methods to extend ACT to patients that cannot be treated with lymphodepleting 
regimens. In a human CD19 CAR-T study, it was reported that high IL-15 plasma levels at the time of CAR-T infusion were associated with the effectiveness of this treatment [123].

In an effort to develop new generation CAR-T cell-based therapy, the sequence encoding for a membrane-bound IL-15 (mbIL-15) fusion protein has been incorporated into the CAR-expressing lentiviral vectors. CD19 CAR-T cells co-expressing mbIL-15 were long-lived, possessed the stem-cell like $\mathrm{CD} 45 \mathrm{RO}^{\text {neg }} \mathrm{CCR} 7^{+}$phenotype, and mediated the rejection of $\mathrm{CD} 19^{+}$leukemia in mice [124]. The employment of tethered IL-15 in combination with CAR-T cells shows promise for interventions against solid tumors. Indeed, coexpression of mbIL-15 in IL-13R $\alpha 2$ CAR-T cells provided benefits in a mouse model of glioblastoma [125]. New generation CAR-T cells co-expressing mbIL-15 displayed high levels of Bcl-2, low levels of PD-1, and were characterized by enhanced tumor localization and effector functions. Their anti-tumor effect was also associated with the modification of the tumor microenvironment, with enhanced NK cell activation and a reduced number of M2 macrophages [126]. Such therapies may raise concerns regarding uncontrolled T cell proliferation as a consequence of the continuous exposure to IL-15. To overcome this issue, a new strategy consists of the incorporation of the suicide gene inducible caspase-9 (iC9) into CD19 CAR-T/mbIL-15 cells. These cells displayed great proliferative capability both in vitro and in vivo, increased survival, a reduced exhaustion phenotype, and improved anti-tumor effects. Additionally, these cells could be safely eliminated through exogenous stimulation of the $\mathrm{iC} 9$ gene [127]. The co-expression of mbIL-15 has also proved advantageous in CD19 CAR-NK against hematological malignancies [128,129].

Overall, both pre-treatment with IL-15 and in vivo combination of IL-15 with CAR-T, CAR-NK and TILs provides advantages to treat cancers (for reviews, see also refs [130-132].

\section{4. $\gamma$-Chain Family of Cytokines}

The anti-cancer effects of IL-15 are based on the activation of $\mathrm{CD}^{+} \mathrm{T}$ and NK cells. Other cytokines belonging to the $\gamma$-chain family exert similar effects and can be used for cancer treatment, either alone or in combination with IL-15. IL-2 is the prototypical cytokine employed as a cancer immunotherapeutic agent. It was approved for clinical use in 1992 for the treatment of certain types of human malignancies, such as melanoma, renal carcinoma, and non-Hodgkin's lymphoma. IL-2 stimulates NK and terminally-differentiated effector $\mathrm{CD}^{+} \mathrm{T}$ cells with high cytolytic activity $[133,134]$. IL-2, as well as other $\gamma$-chain cytokines, have also been reported to support ACT in the B16 mouse melanoma model [135]. However, the role of IL-2 in activation induced cell death (AICD), and in promoting the accumulation of Tregs, especially at low doses [136,137], partially counteracts its anti-tumor effectiveness. Additionally, the use of high-dose recombinant IL-2 is currently limited by the severe toxic effects associated with the therapy such as capillary leak syndrome, hypotension, and renal insufficiency [138]. These detrimental factors have suggested a need for cytokine therapies possessing the immunostimulatory effects of IL-2, but with fewer adverse effects. Among these, the use of IL-2/anti-IL-2R antibody complexes showed promising results in mouse tumor models. The antibody employed in the complexes stabilize the cytokine and favors the specific binding to cells expressing the $\beta / \gamma$ receptor, limiting the activity of IL-2 to $\mathrm{CD}^{+} \mathrm{T}$ and NK cells, but not IL-2R $\alpha^{+}$Tregs [139-143].

\section{IL-15 in Clinical Trials for Cancer Immunotherapy}

The success of IL-15-based immunotherapies in preclinical studies has led the development of several registered clinical trials, involving administration of IL-15 alone or with other immunotherapy. Several delivery routes, including IV, SC and CIV, are currently being tested. An overview is presented in Table 1. 
Table 1. Clinical trials with IL-15.

\begin{tabular}{|c|c|c|c|c|c|c|}
\hline $\begin{array}{c}\text { IL-15 } \\
\text { Agents }\end{array}$ & $\begin{array}{l}\text { Combination } \\
\text { Immunotherapy }\end{array}$ & $\begin{array}{l}\text { Route of IL-15 } \\
\text { Delivery }\end{array}$ & Dose Tested or MTD ${ }^{1}$ & Application & $\begin{array}{l}\text { Best Clinical } \\
\text { Response }\end{array}$ & $\begin{array}{c}\text { NCT/ } \\
\text { Reference }\end{array}$ \\
\hline $\begin{array}{l}\text { sch } \\
\text { rhIL-15 }\end{array}$ & - & IV & $\begin{array}{c}0.3 \mu \mathrm{g} / \mathrm{kg} / \text { dose daily for } \\
12 \text { days }\end{array}$ & $\begin{array}{c}\text { Malignant } \\
\text { melanoma and } \\
\text { renal cell carcinoma }\end{array}$ & SD & [144] \\
\hline $\begin{array}{c}\text { sch } \\
\text { rhIL-15 }\end{array}$ & - & SC & $\begin{array}{c}2 \mu \mathrm{g} / \mathrm{kg} / \mathrm{dose} \\
5 \text { days /week for } 2 \text { weeks }\end{array}$ & $\begin{array}{l}\text { Advanced solid } \\
\text { tumors }\end{array}$ & SD & [145] \\
\hline $\begin{array}{c}\text { sch } \\
\text { rhIL-15 }\end{array}$ & - & CIV & $2 \mu \mathrm{g} / \mathrm{kg} /$ dose for 10 days & Metastatic tumors & SD & [146] \\
\hline $\begin{array}{c}\text { sch } \\
\text { rhIL-15 }\end{array}$ & $\begin{array}{l}\text { Lympho-depleting } \\
\text { regimen and } \\
\text { haploidentical NK } \\
\text { cell infusion }\end{array}$ & $\mathrm{IV} / \mathrm{SC}$ & $\begin{array}{c}0.3 \mu \mathrm{g} / \mathrm{kg} / \mathrm{dose} \text { daily for } \\
12 \text { days IV } ; 2 \mu \mathrm{g} / \mathrm{kg} / \mathrm{dose} \\
\text { for } 10 \text { days SC }\end{array}$ & $\begin{array}{l}\text { Acute myeloid } \\
\text { leukemia }\end{array}$ & $35 \%$ remission & [147] \\
\hline $\begin{array}{c}\text { sch } \\
\text { rhIL-15 }\end{array}$ & $\begin{array}{l}\text { Nivolumab and } \\
\text { Ipilimumab }\end{array}$ & SC & Daily on day $1-8$ and $22-29$ & Refractory cancers & $\begin{array}{l}\text { Active/ } \\
\text { recruiting }\end{array}$ & NCT03388632 \\
\hline $\begin{array}{c}\text { sch } \\
\text { rhIL-15 }\end{array}$ & Avelumab & CIV & $\begin{array}{l}1,2,3 \text { and } 4 \mu \mathrm{g} / \mathrm{kg} / \text { day } \\
\text { for } 5 \text { days (max } 6 \text { cycles) }\end{array}$ & $\begin{array}{l}\text { Refractory } \mathrm{T} \text { cell } \\
\text { malignancies }\end{array}$ & $\begin{array}{l}\text { Active/ } \\
\text { recruiting }\end{array}$ & NCT03905135 \\
\hline $\begin{array}{c}\text { sch } \\
\text { rhIL-15 }\end{array}$ & Obinutuzumab & CIV & $\begin{array}{c}0.5,1 \text { and } 2 \mu \mathrm{g} / \mathrm{kg} / \text { day for } \\
5 \text { days (max } 6 \text { cycles) }\end{array}$ & CLL & $\begin{array}{l}\text { Active/ } \\
\text { recruiting }\end{array}$ & NCT03759184 \\
\hline $\begin{array}{c}\text { sch } \\
\text { rhIL-15 }\end{array}$ & Alemtuzumab & SC & $\begin{array}{c}0.5-2 \mu \mathrm{g} / \mathrm{kg} / \mathrm{dose} \\
5 \text { days } / \text { week for } 2 \text { weeks }\end{array}$ & ATL & $\begin{array}{l}\text { Active/ } \\
\text { recruiting }\end{array}$ & NCT02689453 \\
\hline hetIL-15 (NIZ985) & - & SC & $\begin{array}{c}0.25,0.5,1,2 \text { or } 4 \mu \mathrm{g} / \mathrm{kg} \\
3 \text { times/week for } 2 \text { weeks }\end{array}$ & $\begin{array}{l}\text { Metastatic solid } \\
\text { tumors }\end{array}$ & Active & NCT02452268 \\
\hline hetIL-15 (NIZ985) & $\begin{array}{c}\text { PDR001 } \\
\text { /Spartalizumab }\end{array}$ & SC & $\begin{array}{c}0.25,0.5,1,2 \text { or } 4 \mu \mathrm{g} / \mathrm{kg} \\
3 \text { times } / \text { week for } 2 \text { weeks }\end{array}$ & $\begin{array}{l}\text { Metastatic solid } \\
\text { tumors }\end{array}$ & Active & NCT02452268 \\
\hline hetIL-15 (NIZ985) & Spartalizumab & SC & 2 or $4 \mu \mathrm{g} / \mathrm{kg}$ weekly & $\begin{array}{l}\text { Advanced solid } \\
\text { tumors and } \\
\text { lymphoma } \\
\text { (checkpoint } \\
\text { inhibitors relapsed) }\end{array}$ & Active & NCT04261439 \\
\hline N-803 & - & $\mathrm{IV} / \mathrm{SC}$ & $\begin{array}{c}10 \mu \mathrm{g} / \mathrm{kg} / \text { dose IV for } \\
10 \text { days or SC weekly for } \\
4 \text { weeks }\end{array}$ & $\begin{array}{c}\text { Hematological } \\
\text { malignancies }\end{array}$ & $1 \mathrm{CR}, 1 \mathrm{PR}, 3 \mathrm{SD}$ & [148] \\
\hline $\mathrm{N}-803$ & - & $\mathrm{IV} / \mathrm{SC}$ & $\begin{array}{c}20 \mu \mathrm{g} / \mathrm{kg} / \text { dose weekly for } \\
4 \text { weeks, every } 6 \text { weeks }\end{array}$ & Solid tumors & No response & [149] \\
\hline N-803 & Nivolumab & SC & $\begin{array}{c}20 \mu \mathrm{g} / \mathrm{kg} / \mathrm{dose}+240 \mathrm{mg} \\
\text { nivolumab iv every } \\
2 \text { weeks }\end{array}$ & $\begin{array}{l}\text { Non-small cell lung } \\
\text { carcinoma }\end{array}$ & $6 \mathrm{PR}, 10 \mathrm{SD}$ & [150] \\
\hline $\mathrm{N}-803$ & Rituximab & $\mathrm{IV} / \mathrm{SC}$ & Weekly for 4 weeks & $\begin{array}{c}\text { B-cell } \\
\text { non-Hodgkin's } \\
\text { lymphoma }\end{array}$ & Active & NCT02384954 \\
\hline $\mathrm{N}-803$ & $\begin{array}{l}\text { Pembrolizumab/ } \\
\text { Nivolumab/ } \\
\text { Atezolizumab }\end{array}$ & SC & $\begin{array}{c}15 \mu \mathrm{g} / \mathrm{kg} / \text { dose every } \\
\text { 3 weeks }\end{array}$ & Advanced cancers & $\begin{array}{l}\text { Active/ } \\
\text { recruiting }\end{array}$ & NCT03228667 \\
\hline $\mathrm{N}-803$ & $\begin{array}{l}\text { Standard-of-care } \\
\text { chemotherapy/ } \\
\text { aldoxorubicin HCl/ } \\
\text { PD-L1 t-haNK }\end{array}$ & SC & $\begin{array}{c}15 \mu \mathrm{g} / \mathrm{kg} / \text { dose every } \\
\text { 3 weeks }\end{array}$ & Pancreatic cancer & $\begin{array}{l}\text { Active/ } \\
\text { recruiting }\end{array}$ & NCT04390399 \\
\hline
\end{tabular}

${ }^{1}$ MTD, maximum tolerated dose; NCT, National Clinical Trial; IV, intravenous; SC, subcutaneous; CIV, continuous intravenous infusion; $\mathrm{SD}$, stable disease; $\mathrm{PR}$, partial response; $\mathrm{CR}$, complete response.

\section{1. sch rhIL-15}

The first human phase I trial consisted of the administration of sch rhIL-15 via IV route for 12 consecutive days in patients with metastatic cancers [144]. Toxicity at the doses of 3 and $1 \mu \mathrm{g} / \mathrm{kg} /$ day were observed, while all nine patients treated with a dose of $0.03 \mu \mathrm{g} / \mathrm{kg} /$ dose, identified as the maximum tolerated dose (MTD), were able to complete the treatment without dose-limiting toxicity. At higher doses, the toxicities observed were grade 3 hypotension and thrombocytopenia, as well as persistent elevated aminotransferase levels. Additional adverse effects in patient with $3 \mu \mathrm{g} / \mathrm{kg} /$ day include fever and chills, mostly related to the markedly elevated levels of circulating inflammatory cytokines IL-6 and IFN- $\gamma$. IV treatment with sch rhIL-15 resulted in a rapid extravasation of NK and effector T cells from peripheral blood within minutes after IL-15 delivery, followed by increased proliferation and gradual accumulation of circulating NK, $\gamma \delta$ T and memory 
$\mathrm{CD} 8^{+} \mathrm{T}$ cells [144]. As monotherapy, sch rhIL-15 was also administered via SC route at 0.25 , $0.5,1,2$ and $3 \mu \mathrm{g} / \mathrm{kg} /$ day for five consecutive days for two weeks [145] and by CIV at 0.125, $0.25,0.5,1,2$ and $4 \mu \mathrm{g} / \mathrm{kg} /$ day for 10 consecutive days [146]. Upon SC delivery, serious adverse events included grade 2 pancreatitis and grade 3 cardiac chest pain, associated with hypotension and elevated troponin. The treatment induced a great expansion of circulating NK cells, especially in the CD56 $6^{\text {brigh }}$ subset, and to a lesser extent of CD8 ${ }^{+} \mathrm{T}$ cells at the identified MTD of $2 \mu \mathrm{g} / \mathrm{kg} /$ dose [145]. The major challenges in both IV and SC trials were the short in vivo half-life of sch rhIL-15 and the risk of immunogenicity toward the non-glycosylated cytokine. Upon CIV administration, the highest tested doses induced dose-limiting toxicity and MTD was $2 \mu \mathrm{g} / \mathrm{kg} /$ dose. CIV provided the most effective way to deliver sch rhIL-15. The IL-15 $\mathrm{C}_{\max }$ was at $48 \mathrm{~h}$, followed by a decline to $8 \%$ of maximum level by day 8-10. Similarly to IV administration, at the beginning of CIV treatment, extravasation of $\mathrm{NK}$ and $\mathrm{CD} 8^{+}$memory $\mathrm{T}$ cells occurred, followed by a gradual increase and peak accumulation of circulating lymphocytes shortly after termination of infusion. Patients in the $2 \mu \mathrm{g} / \mathrm{kg}$ / day group showed a remarkable 358-fold increase in circulating CD56 bright NK cells, and 38-fold increase in total NK cells. The number of circulating $\mathrm{CD}^{+} \mathrm{T}$ cells increased by 5.8 -fold [146]. In all three trials, the best response observed was stable disease.

Combination therapy of sch rhIL-15 with other agents is also being explored in the clinic. In two trials, sch rhIL-15 was delivered by IV and SC routes [147] after lymphodepleting regimen and haploidentical NK cell infusion in patients with acute myeloid leukemia, resulting in 35\% remission. Several phase I trials have been initiated, including sch rhIL-15 with nivolumab (a-PD-1) and ipilimumab (a-CTLA4) in refractory cancers (NCT03388632), with avelumab (a-PD-L1; NCT03905135) in T cell malignancies, with obinutuzumab (a-CD20; NCT03759184) in CLL; and with alemtuzumab (a-CD52; NCT02689453) in ATL.

\section{2. hetIL-15 (NIZ985)}

A phase I clinical trial (NCT02452268) has been conducted at the NIH Clinical Center having the following primary objectives: (1) to characterize the safety and tolerability of hetIL-15 in adults with metastatic cancers; (2) to identify the MTD and/or recommended dose for expansion (MTD/RDE) of hetIL-15 (NIZ985). hetIL-15 was delivered subcutaneously three times per week at doses of $0.25,0.5,1,2$ or $4 \mu \mathrm{g} / \mathrm{kg}$ for the first two weeks of each 28-day cycle (manuscript in preparation). Beginning with the first dose level, patients developed erythematous injection site reactions characterized by significant perivascular $\mathrm{T}$ cell infiltration, dermal macrophage infiltration, and accumulation of $\mathrm{CD}^{2} 6^{+}$cells, likely NK cells, at the dermal-epidermal junction. No MTD was reached and stable disease was the best response. NIZ985 treatment was associated with increases in several cytokines, including IFN- $\gamma$, IL-18, CXCL10, and TNF- $\beta$, plus significant induction of cytotoxic lymphocyte proliferation (including $\mathrm{NK}$ and $\mathrm{CD} 8^{+} \mathrm{T}$ cells). A phase $\mathrm{I} / \mathrm{Ib}$ multicenter study of hetIL-15 (NIZ985) in combination with PDR001 (Anti-PD-1) in adults with metastatic cancers has also being initiated with the objectives: (1) to characterize the safety and tolerability of hetIL-15 alone and in combination with PDR001; and (2) to identify the MTD/RDE of hetIL-15 alone and in combination with PDR001. The clinical study has been expanded to a multicenter study (NCT02452268). An additional study combining hetIL-15 delivered via SC route with spartalizumab has been initiated in Japan in patients with advanced solid tumors and lymphoma who have progressed after obtaining a previous response to checkpoint inhibitor therapy (NCT04261439).

\subsection{N-803 (Anktiva, Formerly ALT-803)}

$\mathrm{N}-803$ was administered to patients with hematological malignancies once weekly for four weeks, at doses of 1,3, 6 and $10 \mu \mathrm{g} / \mathrm{kg} /$ dose via IV route and at doses of 6 and $10 \mu \mathrm{g} / \mathrm{kg} /$ dose via SC route [148], and to patients with advanced solid tumors for four consecutive weeks, every six weeks at a dose of $20 \mu \mathrm{g} / \mathrm{kg} /$ dose, via IV or SC routes, 
respectively [149]. No dose-limiting toxicities were observed. IV injections were associated with fatigue and nausea, related to the plasma spike in IL-6 and IFN- $\gamma$ [149]. SC administration resulted in large, painful erythematous plaques at the injection site, associated with infiltration of CD56 ${ }^{+} \mathrm{NKp} 46^{-} \gamma \delta \mathrm{T}$ cells [148]. Pharmacokinetic analysis showed prolonged serum concentrations with a peak between $2 \mathrm{~h}$ and $6 \mathrm{~h}$ following SC, but not IV, injection. $\mathrm{N}-803$ stimulated the proliferation and activation of circulating NK cells and CD8 ${ }^{+} \mathrm{T}$ cells, without affecting Tregs [148]. In patients with hematological malignancies, responses were observed in $19 \%$ of patients, with three patients presenting stable disease, one with partial response, and one with complete remission lasting longer than seven months [148]. No responses were observed in patients with solid tumors [149]. Low-titer antibodies in one treated patient was reported [148]. A phase I trials of N-803 delivered subcutaneously in combination with nivolumab in patients with metastatic non-small cell lung cancer has also been conducted [150]. The treatment was well-tolerated, with the most common adverse effects being injection site reactions, flu-like symptoms, and fatigue. A grade 3 myocardial infarction occurred in one patient. MTD was not reached, and the recommended dose for phase II was $20 \mu \mathrm{g} / \mathrm{kg} \mathrm{N}-803$ given once per week subcutaneously, in combination with $240 \mathrm{mg}$ IV nivolumab every two weeks. Changes in peripheral blood mainly affected NK cells (three-fold increase) and were more modest in $\mathrm{CD}^{+} \mathrm{T}$ cells. Stable disease and partial responses were observed in 10 and 6 of 21 patients, respectively. Antibodies against N-803 were found in 33\% of the treated patients [150]. More combination trials are ongoing with rituximab (NCT02384954) and pembrolizumab/nivolumab/atezolizumab (NCT03228667).

\section{Conclusions}

IL-15 is a promising agent for cancer immunotherapy. IL-15 functions by stimulating effector immune cells capable of killing cancer cells. Several preclinical studies have shown that IL-15 promotes tumor infiltration of both lymphocytes and dendritic cells, through the induction of several cytokines, and supports the proliferation, survival, and cytotoxic activity of both $\mathrm{CD}^{+} \mathrm{T}$ and NK cells. Despite the success of sch rhIL-15 in preclinical studies, its use in clinics is limited by the short half-life in vivo and potential toxicity associated with high-dose delivery. IL-15 is produced in the body as a heterodimeric cytokine comprising the IL-15 and IL-15R $\alpha$ chains, named hetIL-15. Both hetIL-15 and variants of IL-15:IL-15R $\alpha$ complexes (N-803 and RLI) showed improved pharmacokinetics and anti-tumor activity in animal models and in humans. The hetIL-15 molecule has certain advantages compared to the other versions of IL-15, currently in clinical trials, which are: (i) single-chain IL-15 produced in E. coli [53] has a short plasma half-life [144] and is immunogenic in humans; and (ii) N-803 has altered structure and glycosylation and may be immunogenic in humans $[148,150]$. In contrast, hetIL-15 represents the endogenous molecule circulating in the blood, and no antibodies against it have been detected so far after administration in humans. The available data suggest that N-803 and hetIL-15 have comparable biological activities.

Current challenges aim to identify optimal dosing schemes and routes of administration to maximize anti-tumor effects and minimize toxicity; and to select optimal combinations with other anti-cancer agents and immunotherapies.

Author Contributions: C.B. wrote the review; V.S., D.S., S.K., B.K.F. and G.N.P. contributed to the writing and editing of the review. All authors have read and agreed to the published version of the manuscript.

Funding: This work was funded in part by the Intramural Research Program of the National Cancer Institute, National Institutes of Health (NCI/NIH). The support of Admune/Novartis and Gilead for hetIL-15 studies is acknowledged.

Acknowledgments: We thank T. Jones for editorial assistance.

Conflicts of Interest: The authors declare no conflict of interest. 


\section{References}

1. Ma, A.; Koka, R.; Burkett, P. Diverse functions of IL-2, IL-15, and IL-7 in lymphoid homeostasis. Annu. Rev. Immunol. 2006, 24, 657-679. [CrossRef]

2. Waldmann, T.A. The biology of interleukin-2 and interleukin-15: Implications for cancer therapy and vaccine design. Nat. Rev. Immunol. 2006, 6, 595-601. [CrossRef] [PubMed]

3. Sprent, J.; Cho, J.H.; Boyman, O.; Surh, C.D. T cell homeostasis. Immunol. Cell Biol. 2008, 86, 312-319. [CrossRef] [PubMed]

4. Boyman, O.; Purton, J.F.; Surh, C.D.; Sprent, J. Cytokines and T-cell homeostasis. Curr. Opin. Immunol. 2007, 19, 320-326. [CrossRef] [PubMed]

5. Surh, C.D.; Boyman, O.; Purton, J.F.; Sprent, J. Homeostasis of memory T cells. Immunol. Rev. 2006, 211, 154-163. [CrossRef] [PubMed]

6. Berard, M.; Brandt, K.; Bulfone-Paus, S.; Tough, D.F. IL-15 promotes the survival of naive and memory phenotype CD8+ T cells. J. Immunol. 2003, 170, 5018-5026. [CrossRef] [PubMed]

7. Carson, W.E.; Giri, J.G.; Lindemann, M.J.; Linett, M.L.; Ahdieh, M.; Paxton, R.; Anderson, D.; Eisenmann, J.; Grabstein, K.; Caligiuri, M.A. Interleukin (IL) 15 is a novel cytokine that activates human natural killer cells via components of the IL-2 receptor. J. Exp. Med. 1994, 180, 1395-1403. [CrossRef]

8. Zhang, X.; Sun, S.; Hwang, I.; Tough, D.F.; Sprent, J. Potent and selective stimulation of memory-phenotype CD8+ T cells in vivo by IL-15. Immunity 1998, 8, 591-599. [CrossRef]

9. Lotze, M.T.; Chang, A.E.; Seipp, C.A.; Simpson, C.; Vetto, J.T.; Rosenberg, S.A. High-dose recombinant interleukin 2 in the treatment of patients with disseminated cancer. Responses, treatment-related morbidity, and histologic findings. JAMA 1986, 256, 3117-3124. [CrossRef] [PubMed]

10. Rosenberg, S.A.; Lotze, M.T.; Muul, L.M.; Leitman, S.; Chang, A.E.; Ettinghausen, S.E.; Matory, Y.L.; Skibber, J.M.; Shiloni, E.; Vetto, J.T.; et al. Observations on the systemic administration of autologous lymphokine-activated killer cells and recombinant interleukin-2 to patients with metastatic cancer. N. Engl. J. Med. 1985, 313, 1485-1492. [CrossRef] [PubMed]

11. Giri, J.G.; Ahdieh, M.; Eisenman, J.; Shanebeck, K.; Grabstein, K.; Kumaki, S.; Namen, A.; Park, L.S.; Cosman, D.; Anderson, D. Utilization of the beta and gamma chains of the IL-2 receptor by the novel cytokine IL-15. EMBO J. 1994, 13, 2822-2830. [CrossRef]

12. Sadlack, B.; Merz, H.; Schorle, H.; Schimpl, A.; Feller, A.C.; Horak, I. Ulcerative colitis-like disease in mice with a disrupted interleukin-2 gene. Cell 1993, 75, 253-261. [CrossRef]

13. Malek, T.R.; Porter, B.O.; Codias, E.K.; Scibelli, P.; Yu, A. Normal lymphoid homeostasis and lack of lethal autoimmunity in mice containing mature T cells with severely impaired IL-2 receptors. J. Immunol. 2000, 164, 2905-2914. [CrossRef] [PubMed]

14. Malek, T.R.; Yu, A.; Vincek, V.; Scibelli, P.; Kong, L. CD4 regulatory T cells prevent lethal autoimmunity in IL-2Rbeta-deficient mice. Implications for the nonredundant function of IL-2. Immunity 2002, 17, 167-178. [CrossRef]

15. Spolski, R.; Li, P.; Leonard, W.J. Biology and regulation of IL-2: From molecular mechanisms to human therapy. Nat. Rev. Immunol. 2018, 18, 648-659. [CrossRef]

16. Kennedy, M.K.; Glaccum, M.; Brown, S.N.; Butz, E.A.; Viney, J.L.; Embers, M.; Matsuki, N.; Charrier, K.; Sedger, L.; Willis, C.R.; et al. Reversible defects in natural killer and memory CD8 T cell lineages in interleukin 15-deficient mice. J. Exp. Med. 2000, 191, 771-780. [CrossRef] [PubMed]

17. Colpitts, S.L.; Stonier, S.W.; Stoklasek, T.A.; Root, S.H.; Aguila, H.L.; Schluns, K.S.; Lefrancois, L. Transcriptional regulation of IL-15 expression during hematopoiesis. J. Immunol. 2013, 191, 3017-3024. [CrossRef] [PubMed]

18. Cui, G.; Hara, T.; Simmons, S.; Wagatsuma, K.; Abe, A.; Miyachi, H.; Kitano, S.; Ishii, M.; Tani-ichi, S.; Ikuta, K. Characterization of the IL-15 niche in primary and secondary lymphoid organs in vivo. Proc. Natl. Acad. Sci. USA 2014, 111, 1915-1920. [CrossRef]

19. Giri, J.G.; Kumaki, S.; Ahdieh, M.; Friend, D.J.; Loomis, A.; Shanebeck, K.; DuBose, R.; Cosman, D.; Park, L.S.; Anderson, D.M. Identification and cloning of a novel IL-15 binding protein that is structurally related to the alpha chain of the IL-2 receptor. EMBO J. 1995, 14, 3654-3663. [CrossRef] [PubMed]

20. Bergamaschi, C.; Bear, J.; Rosati, M.; Beach, R.K.; Alicea, C.; Sowder, R.; Chertova, E.; Rosenberg, S.A.; Felber, B.K.; Pavlakis, G.N. Circulating IL-15 exists as heterodimeric complex with soluble IL-15Ralpha in human and mouse serum. Blood 2012, 120, e1-e8. [CrossRef] [PubMed]

21. Grabstein, K.H.; Eisenman, J.; Shanebeck, K.; Rauch, C.; Srinivasan, S.; Fung, V.; Beers, C.; Richardson, J.; Schoenborn, M.A.; Ahdieh, M.; et al. Cloning of a T cell growth factor that interacts with the beta chain of the interleukin-2 receptor. Science 1994, 264, 965-968. [CrossRef] [PubMed]

22. Burton, J.D.; Bamford, R.N.; Peters, C.; Grant, A.J.; Kurys, G.; Goldman, C.K.; Brennan, J.; Roessler, E.; Waldmann, T.A. A lymphokine, provisionally designated interleukin $\mathrm{T}$ and produced by a human adult T-cell leukemia line, stimulates T-cell proliferation and the induction of lymphokine-activated killer cells. Proc. Natl. Acad. Sci. USA 1994, 91, 4935-4939. [CrossRef]

23. Chirifu, M.; Hayashi, C.; Nakamura, T.; Toma, S.; Shuto, T.; Kai, H.; Yamagata, Y.; Davis, S.J.; Ikemizu, S. Crystal structure of the IL-15-IL-15Ralpha complex, a cytokine-receptor unit presented in trans. Nat. Immunol. 2007, 8, 1001-1007. [CrossRef] [PubMed]

24. Villinger, F.; Brar, S.S.; Mayne, A.; Chikkala, N.; Ansari, A.A. Comparative sequence analysis of cytokine genes from human and nonhuman primates. J. Immunol. 1995, 155, 3946-3954. [PubMed]

25. Anderson, D.M.; Johnson, L.; Glaccum, M.B.; Copeland, N.G.; Gilbert, D.J.; Jenkins, N.A.; Valentine, V.; Kirstein, M.N.; Shapiro, D.N.; Morris, S.W.; et al. Chromosomal assignment and genomic structure of Il15. Genomics 1995, 25, 701-706. [CrossRef] 
26. Tagaya, Y.; Bamford, R.N.; DeFilippis, A.P.; Waldmann, T.A. IL-15: A pleiotropic cytokine with diverse receptor/signaling pathways whose expression is controlled at multiple levels. Immunity 1996, 4, 329-336. [CrossRef]

27. Waldmann, T.A.; Tagaya, Y. The multifaceted regulation of interleukin-15 expression and the role of this cytokine in NK cell differentiation and host response to intracellular pathogens. Annu. Rev. Immunol. 1999, 17, 19-49. [CrossRef]

28. Dubois, S.; Mariner, J.; Waldmann, T.A.; Tagaya, Y. IL-15Ralpha recycles and presents IL-15 In trans to neighboring cells. Immunity 2002, 17, 537-547. [CrossRef]

29. Burkett, P.R.; Koka, R.; Chien, M.; Chai, S.; Boone, D.L.; Ma, A. Coordinate expression and trans presentation of interleukin (IL)-15Ralpha and IL-15 supports natural killer cell and memory CD8+ T cell homeostasis. J. Exp. Med. 2004, 200, 825-834. [CrossRef]

30. Koka, R.; Burkett, P.R.; Chien, M.; Chai, S.; Chan, F.; Lodolce, J.P.; Boone, D.L.; Ma, A. Interleukin (IL)-15R[alpha]-deficient natural killer cells survive in normal but not IL-15R[alpha]-deficient mice. J. Exp. Med. 2003, 197, 977-984. [CrossRef]

31. Sandau, M.M.; Schluns, K.S.; Lefrancois, L.; Jameson, S.C. Cutting edge: Transpresentation of IL-15 by bone marrow-derived cells necessitates expression of IL-15 and IL-15R alpha by the same cells. J. Immunol. 2004, 173, 6537-6541. [CrossRef] [PubMed]

32. Ruckert, R.; Brandt, K.; Bulanova, E.; Mirghomizadeh, F.; Paus, R.; Bulfone-Paus, S. Dendritic cell-derived IL-15 controls the induction of CD8 T cell immune responses. Eur. J. Immunol. 2003, 33, 3493-3503. [CrossRef] [PubMed]

33. Azimi, N.; Nagai, M.; Jacobson, S.; Waldmann, T.A. IL-15 plays a major role in the persistence of Tax-specific CD8 cells in HAM/TSP patients. Proc. Natl. Acad. Sci. USA 2001, 98, 14559-14564. [CrossRef] [PubMed]

34. Mariner, J.M.; Mamane, Y.; Hiscott, J.; Waldmann, T.A.; Azimi, N. IFN regulatory factor 4 participates in the human T cell lymphotropic virus type I-mediated activation of the IL-15 receptor alpha promoter. J. Immunol. 2002, 168, 5667-5674. [CrossRef] [PubMed]

35. Bergamaschi, C.; Rosati, M.; Jalah, R.; Valentin, A.; Kulkarni, V.; Alicea, C.; Zhang, G.M.; Patel, V.; Felber, B.K.; Pavlakis, G.N Intracellular interaction of Interleukin-15 with its Receptor \{alpha\} during production leads to mutual stabilization and increased bioactivity. J. Biol. Chem. 2008, 283, 4189-4199. [CrossRef] [PubMed]

36. Mortier, E.; Woo, T.; Advincula, R.; Gozalo, S.; Ma, A. IL-15Ralpha chaperones IL-15 to stable dendritic cell membrane complexes that activate NK cells via trans presentation. J. Exp. Med. 2008, 205, 1213-1225. [CrossRef] [PubMed]

37. Bergamaschi, C.; Jalah, R.; Kulkarni, V.; Rosati, M.; Zhang, G.M.; Alicea, C.; Zolotukhin, A.S.; Felber, B.K.; Pavlakis, G.N. Secretion and biological activity of short signal peptide IL-15 is chaperoned by IL-15 receptor alpha in vivo. J. Immunol. 2009, 183, 3064-3072. [CrossRef] [PubMed]

38. Rubinstein, M.P.; Kovar, M.; Purton, J.F.; Cho, J.H.; Boyman, O.; Surh, C.D.; Sprent, J. Converting IL-15 to a superagonist by binding to soluble IL-15R \{alpha\}. Proc. Natl. Acad. Sci. USA 2006, 103, 9166-9171. [CrossRef]

39. Stoklasek, T.A.; Schluns, K.S.; Lefrancois, L. Combined IL-15/IL-15Ralpha immunotherapy maximizes IL-15 activity in vivo. J. Immunol. 2006, 177, 6072-6080. [CrossRef]

40. Burkett, P.R.; Koka, R.; Chien, M.; Chai, S.; Chan, F.; Ma, A.; Boone, D.L. IL-15R alpha expression on CD8+ T cells is dispensable for T cell memory. Proc. Natl. Acad. Sci. USA 2003, 100, 4724-4729. [CrossRef]

41. Koka, R.; Burkett, P.; Chien, M.; Chai, S.; Boone, D.L.; Ma, A. Cutting edge: Murine dendritic cells require IL-15R alpha to prime NK cells. J. Immunol. 2004, 173, 3594-3598. [CrossRef] [PubMed]

42. Schluns, K.S.; Klonowski, K.D.; Lefrancois, L. Transregulation of memory CD8 T-cell proliferation by IL-15Ralpha+ bone marrow-derived cells. Blood 2004, 103, 988-994. [CrossRef] [PubMed]

43. Huntington, N.D.; Legrand, N.; Alves, N.L.; Jaron, B.; Weijer, K.; Plet, A.; Corcuff, E.; Mortier, E.; Jacques, Y.; Spits, H.; et al. IL-15 trans-presentation promotes human NK cell development and differentiation in vivo. J. Exp. Med. 2009, 206, 25-34. [CrossRef]

44. Lucas, M.; Schachterle, W.; Oberle, K.; Aichele, P.; Diefenbach, A. Dendritic cells prime natural killer cells by trans-presenting interleukin 15. Immunity 2007, 26, 503-517. [CrossRef]

45. Stonier, S.W.; Ma, L.J.; Castillo, E.F.; Schluns, K.S. Dendritic cells drive memory CD8 T-cell homeostasis via IL-15 transpresentation. Blood 2008, 112, 4546-4554. [CrossRef]

46. Jonuleit, H.; Wiedemann, K.; Muller, G.; Degwert, J.; Hoppe, U.; Knop, J.; Enk, A.H. Induction of IL-15 messenger RNA and protein in human blood-derived dendritic cells: A role for IL-15 in attraction of T cells. J. Immunol. 1997, 158, 2610-2615. [PubMed]

47. Carson, W.E.; Ross, M.E.; Baiocchi, R.A.; Marien, M.J.; Boiani, N.; Grabstein, K.; Caligiuri, M.A. Endogenous production of interleukin 15 by activated human monocytes is critical for optimal production of interferon-gamma by natural killer cells in vitro. J. Clin. Investig. 1995, 96, 2578-2582. [CrossRef]

48. Doherty, T.M.; Seder, R.A.; Sher, A. Induction and regulation of IL-15 expression in murine macrophages. J. Immunol. 1996, 156, 735-741. [PubMed]

49. Mortier, E.; Advincula, R.; Kim, L.; Chmura, S.; Barrera, J.; Reizis, B.; Malynn, B.A.; Ma, A. Macrophage- and dendritic-cell-derived interleukin-15 receptor alpha supports homeostasis of distinct CD8+ T cell subsets. Immunity 2009, 31, 811-822. [CrossRef]

50. Spranger, S.; Koblish, H.K.; Horton, B.; Scherle, P.A.; Newton, R.; Gajewski, T.F. Mechanism of tumor rejection with doublets of CTLA-4, PD-1/PD-L1, or IDO blockade involves restored IL-2 production and proliferation of CD8(+) T cells directly within the tumor microenvironment. J. Immunother. Cancer 2014, 2, 3. [CrossRef]

51. Spranger, S.; Sivan, A.; Corrales, L.; Gajewski, T.F. Tumor and host factors controlling antitumor immunity and efficacy of cancer immunotherapy. Adv. Immunol. 2016, 130, 75-93. [CrossRef] 
52. Tumeh, P.C.; Harview, C.L.; Yearley, J.H.; Shintaku, I.P.; Taylor, E.J.; Robert, L.; Chmielowski, B.; Spasic, M.; Henry, G.; Ciobanu, V.; et al. PD-1 blockade induces responses by inhibiting adaptive immune resistance. Nature 2014, 515, 568-571. [CrossRef] [PubMed]

53. Vyas, V.V.; Esposito, D.; Sumpter, T.L.; Broadt, T.L.; Hartley, J.; Knapp, G.C.t.; Cheng, W.; Jiang, M.S.; Roach, J.M.; Yang, X.; et al. Clinical manufacturing of recombinant human interleukin 15. I. Production cell line development and protein expression in E. coli with stop codon optimization. Biotechnol. Prog. 2011, 28, 497-507. [CrossRef] [PubMed]

54. Chertova, E.; Bergamaschi, C.; Chertov, O.; Sowder, R.; Bear, J.; Roser, J.D.; Beach, R.K.; Lifson, J.D.; Felber, B.K.; Pavlakis, G.N. Characterization and favorable in vivo properties of heterodimeric soluble IL-15.IL-15Ralpha cytokine compared to IL-15 monomer. J. Biol. Chem. 2013, 288, 18093-18103. [CrossRef] [PubMed]

55. Han, K.P.; Zhu, X.; Liu, B.; Jeng, E.; Kong, L.; Yovandich, J.L.; Vyas, V.V.; Marcus, W.D.; Chavaillaz, P.A.; Romero, C.A.; et al. IL-15:IL-15 receptor alpha superagonist complex: High-level co-expression in recombinant mammalian cells, purification and characterization. Cytokine 2011, 56, 804-810. [CrossRef] [PubMed]

56. Mortier, E.; Quemener, A.; Vusio, P.; Lorenzen, I.; Boublik, Y.; Grotzinger, J.; Plet, A.; Jacques, Y. Soluble interleukin-15 receptor alpha (IL-15R alpha)-sushi as a selective and potent agonist of IL-15 action through IL-15R beta/gamma. Hyperagonist IL-15 $x$ IL-15R alpha fusion proteins. J. Biol. Chem. 2006, 281, 1612-1619. [CrossRef] [PubMed]

57. Lugli, E.; Goldman, C.K.; Perera, L.P.; Smedley, J.; Pung, R.; Yovandich, J.L.; Creekmore, S.P.; Waldmann, T.A.; Roederer, M. Transient and persistent effects of IL-15 on lymphocyte homeostasis in nonhuman primates. Blood 2010, 116, 3238-3248. [CrossRef] [PubMed]

58. Sneller, M.C.; Kopp, W.C.; Engelke, K.J.; Yovandich, J.L.; Creekmore, S.P.; Waldmann, T.A.; Lane, H.C. IL-15 administered by continuous infusion to rhesus macaques induces massive expansion of CD8+ T effector memory population in peripheral blood. Blood 2012, 118, 6845-6848. [CrossRef]

59. Picker, L.J.; Reed-Inderbitzin, E.F.; Hagen, S.I.; Edgar, J.B.; Hansen, S.G.; Legasse, A.; Planer, S.; Piatak, M., Jr.; Lifson, J.D.; Maino, V.C.; et al. IL-15 induces CD4 effector memory T cell production and tissue emigration in nonhuman primates. J. Clin. Investig. 2006, 116, 1514-1524. [CrossRef]

60. Waldmann, T.A.; Lugli, E.; Roederer, M.; Perera, L.P.; Smedley, J.V.; Macallister, R.P.; Goldman, C.K.; Bryant, B.R.; Decker, J.M.; Fleisher, T.A.; et al. Safety (toxicity), pharmacokinetics, immunogenicity, and impact on elements of the normal immune system of recombinant human IL-15 in rhesus macaques. Blood 2011, 117, 4787-4795. [CrossRef]

61. Klebanoff, C.A.; Finkelstein, S.E.; Surman, D.R.; Lichtman, M.K.; Gattinoni, L.; Theoret, M.R.; Grewal, N.; Spiess, P.J.; Antony, P.A.; Palmer, D.C.; et al. IL-15 enhances the in vivo antitumor activity of tumor-reactive CD8+ T cells. Proc. Natl. Acad. Sci. USA 2004, 101, 1969-1974. [CrossRef]

62. Kobayashi, H.; Dubois, S.; Sato, N.; Sabzevari, H.; Sakai, Y.; Waldmann, T.A.; Tagaya, Y. Role of trans-cellular IL-15 presentation in the activation of NK cell-mediated killing, which leads to enhanced tumor immunosurveillance. Blood 2005, 105, 721-727. [CrossRef]

63. Munger, W.; DeJoy, S.Q.; Jeyaseelan, R., Sr.; Torley, L.W.; Grabstein, K.H.; Eisenmann, J.; Paxton, R.; Cox, T.; Wick, M.M.; Kerwar, S.S. Studies evaluating the antitumor activity and toxicity of interleukin-15, a new $\mathrm{T}$ cell growth factor: Comparison with interleukin-2. Cell. Immunol. 1995, 165, 289-293. [CrossRef]

64. Tang, F.; Zhao, L.T.; Jiang, Y.; Ba de, N.; Cui, L.X.; He, W. Activity of recombinant human interleukin-15 against tumor recurrence and metastasis in mice. Cell. Mol. Immunol. 2008, 5, 189-196. [CrossRef]

65. Yu, P.; Steel, J.C.; Zhang, M.; Morris, J.C.; Waitz, R.; Fasso, M.; Allison, J.P.; Waldmann, T.A. Simultaneous inhibition of two regulatory T-cell subsets enhanced Interleukin-15 efficacy in a prostate tumor model. Proc. Natl. Acad. Sci. USA 2012, 109, 6187-6192. [CrossRef]

66. Yu, P.; Steel, J.C.; Zhang, M.; Morris, J.C.; Waldmann, T.A. Simultaneous blockade of multiple immune system inhibitory checkpoints enhances antitumor activity mediated by interleukin-15 in a murine metastatic colon carcinoma model. Clin. Cancer Res. 2010, 16, 6019-6028. [CrossRef] [PubMed]

67. Zhang, M.; Ju, W.; Yao, Z.; Yu, P.; Wei, B.R.; Simpson, R.M.; Waitz, R.; Fasso, M.; Allison, J.P.; Waldmann, T.A. Augmented IL-15Ralpha expression by CD40 activation is critical in synergistic CD8 T cell-mediated antitumor activity of anti-CD40 antibody with IL-15 in TRAMP-C2 tumors in mice. J. Immunol. 2012, 188, 6156-6164. [CrossRef] [PubMed]

68. Thaysen-Andersen, M.; Chertova, E.; Bergamaschi, C.; Moh, E.S.; Chertov, O.; Roser, J.; Sowder, R.; Bear, J.; Lifson, J.; Packer, N.H.; et al. Recombinant human heterodimeric IL-15 complex displays extensive and reproducible N- and O-linked glycosylation. Glycoconj. J. 2016, 33, 417-433. [CrossRef] [PubMed]

69. Bergamaschi, C.; Watson, D.C.; Valentin, A.; Bear, J.; Peer, C.J.; Figg, W.D., Sr.; Felber, B.K.; Pavlakis, G.N. Optimized administration of hetIL-15 expands lymphocytes and minimizes toxicity in rhesus macaques. Cytokine 2018. [CrossRef] [PubMed]

70. Watson, D.C.; Moysi, E.; Valentin, A.; Bergamaschi, C.; Devasundaram, S.; Fortis, S.P.; Bear, J.; Chertova, E.; Bess, J., Jr.; Sowder, R.; et al. Treatment with native heterodimeric IL-15 increases cytotoxic lymphocytes and reduces SHIV RNA in lymph nodes. PLoS Pathog. 2018, 14, e1006902. [CrossRef]

71. Bergamaschi, C.; Pandit, H.; Nagy, B.A.; Stellas, D.; Jensen, S.M.; Bear, J.; Cam, M.; Valentin, A.; Fox, B.A.; Felber, B.K.; et al. Heterodimeric IL-15 delays tumor growth and promotes intratumoral CTL and dendritic cell accumulation by a cytokine network involving XCL1, IFN-gamma, CXCL9 and CXCL10. J. Immunother. Cancer 2020, 8. [CrossRef] [PubMed] 
72. Ng, S.S.; Nagy, B.A.; Jensen, S.M.; Hu, X.; Alicea, C.; Fox, B.A.; Felber, B.K.; Bergamaschi, C.; Pavlakis, G.N. Heterodimeric IL-15 treatment enhances tumor infiltration, persistence and effector functions of adoptively transferred tumor-specific T cells in the absence of lymphodepletion. Clin. Cancer Res. 2017, 23, 2817-2830. [CrossRef]

73. Mlecnik, B.; Bindea, G.; Angell, H.K.; Sasso, M.S.; Obenauf, A.C.; Fredriksen, T.; Lafontaine, L.; Bilocq, A.M.; Kirilovsky, A.; Tosolini, M.; et al. Functional network pipeline reveals genetic determinants associated with in situ lymphocyte proliferation and survival of cancer patients. Sci. Transl. Med. 2014, 6, 228ra237. [CrossRef] [PubMed]

74. Dubois, S.; Patel, H.J.; Zhang, M.; Waldmann, T.A.; Muller, J.R. Preassociation of IL-15 with IL-15R alpha-IgG1-Fc enhances its activity on proliferation of NK and CD8+/CD44high T cells and its antitumor action. J. Immunol. 2008, 180, 2099-2106. [CrossRef]

75. Elpek, K.G.; Rubinstein, M.P.; Bellemare-Pelletier, A.; Goldrath, A.W.; Turley, S.J. Mature natural killer cells with phenotypic and functional alterations accumulate upon sustained stimulation with IL-15/IL-15Ralpha complexes. Proc. Natl. Acad. Sci. USA 2010, 107, 21647-21652. [CrossRef] [PubMed]

76. Epardaud, M.; Elpek, K.G.; Rubinstein, M.P.; Yonekura, A.R.; Bellemare-Pelletier, A.; Bronson, R.; Hamerman, J.A.; Goldrath, A.W.; Turley, S.J. Interleukin-15/interleukin-15R alpha complexes promote destruction of established tumors by reviving tumor-resident CD8+ T cells. Cancer Res. 2008, 68, 2972-2983. [CrossRef]

77. Hong, E.; Usiskin, I.M.; Bergamaschi, C.; Hanlon, D.J.; Edelson, R.L.; Justesen, S.; Pavlakis, G.N.; Flavell, R.A.; Fahmy, T.M. Configuration-dependent presentation of multivalent IL-15:IL-15Ralpha enhances the antigen-specific T cell response and anti-tumor immunity. J. Biol. Chem. 2015. [CrossRef]

78. Zhu, X.; Marcus, W.D.; Xu, W.; Lee, H.I.; Han, K.; Egan, J.O.; Yovandich, J.L.; Rhode, P.R.; Wong, H.C. Novel human interleukin-15 agonists. J. Immunol. 2009, 183, 3598-3607. [CrossRef]

79. Kim, P.S.; Kwilas, A.R.; Xu, W.; Alter, S.; Jeng, E.K.; Wong, H.C.; Schlom, J.; Hodge, J.W. IL-15 superagonist/IL-15RalphaSushi-Fc fusion complex (IL-15SA/IL-15RalphaSu-Fc; ALT-803) markedly enhances specific subpopulations of NK and memory CD8+ $\mathrm{T}$ cells, and mediates potent anti-tumor activity against murine breast and colon carcinomas. Oncotarget 2016, 7, 16130-16145. [CrossRef]

80. Liu, B.; Jones, M.; Kong, L.; Noel, T.; Jeng, E.K.; Shi, S.; England, C.G.; Alter, S.; Miller, J.S.; Cai, W.; et al. Evaluation of the biological activities of the IL-15 superagonist complex, ALT-803, following intravenous versus subcutaneous administration in murine models. Cytokine 2018. [CrossRef] [PubMed]

81. Rhode, P.R.; Egan, J.O.; Xu, W.; Hong, H.; Webb, G.M.; Chen, X.; Liu, B.; Zhu, X.; Wen, J.; You, L.; et al. Comparison of the superagonist complex, ALT-803, to IL15 as cancer immunotherapeutics in animal models. Cancer Immunol. Res. 2016, 4, 49-60. [CrossRef] [PubMed]

82. Xu, W.; Jones, M.; Liu, B.; Zhu, X.; Johnson, C.B.; Edwards, A.C.; Kong, L.; Jeng, E.K.; Han, K.; Marcus, W.D.; et al. Efficacy and mechanism-of-action of a novel superagonist interleukin-15: Interleukin-15 receptor alphaSu/Fc fusion complex in syngeneic murine models of multiple myeloma. Cancer Res. 2013, 73, 3075-3086. [CrossRef] [PubMed]

83. Mathios, D.; Park, C.K.; Marcus, W.D.; Alter, S.; Rhode, P.R.; Jeng, E.K.; Wong, H.C.; Pardoll, D.M.; Lim, M. Therapeutic administration of IL-15 superagonist complex ALT-803 leads to long-term survival and durable antitumor immune response in a murine glioblastoma model. Int. J. Cancer 2016, 138, 187-194. [CrossRef]

84. Felices, M.; Chu, S.; Kodal, B.; Bendzick, L.; Ryan, C.; Lenvik, A.J.; Boylan, K.L.M.; Wong, H.C.; Skubitz, A.P.N.; Miller, J.S.; et al. IL-15 super-agonist (ALT-803) enhances natural killer (NK) cell function against ovarian cancer. Gynecol. Oncol. 2017, 145, 453-461. [CrossRef]

85. Rosario, M.; Liu, B.; Kong, L.; Collins, L.I.; Schneider, S.E.; Chen, X.; Han, K.; Jeng, E.K.; Rhode, P.R.; Leong, J.W.; et al. The IL-15-Based ALT-803 complex enhances FcgammaRIIIa-triggered NK cell responses and in vivo clearance of B cell lymphomas. Clin. Cancer Res. 2016, 22, 596-608. [CrossRef] [PubMed]

86. Bessard, A.; Sole, V.; Bouchaud, G.; Quemener, A.; Jacques, Y. High antitumor activity of RLI, an interleukin-15 (IL-15)-IL-15 receptor alpha fusion protein, in metastatic melanoma and colorectal cancer. Mol. Cancer Ther. 2009, 8, 2736-2745. [CrossRef]

87. Desbois, M.; Beal, C.; Charrier, M.; Besse, B.; Meurice, G.; Cagnard, N.; Jacques, Y.; Bechard, D.; Cassard, L.; Chaput, N. IL-15 superagonist RLI has potent immunostimulatory properties on NK cells: Implications for antimetastatic treatment. J. Immunother. Cancer 2020, 8. [CrossRef] [PubMed]

88. Bergamaschi, C.; Kulkarni, V.; Rosati, M.; Alicea, C.; Jalah, R.; Chen, S.; Bear, J.; Sardesai, N.Y.; Valentin, A.; Felber, B.K.; et al. Intramuscular delivery of heterodimeric IL-15 DNA in macaques produces systemic levels of bioactive cytokine inducing proliferation of NK and T cells. Gene Ther. 2015, 22, 76-86. [CrossRef]

89. Quinn, L.S.; Anderson, B.G.; Strait-Bodey, L.; Wolden-Hanson, T. Serum and muscle interleukin-15 levels decrease in aging mice: Correlation with declines in soluble interleukin-15 receptor alpha expression. Exp. Gerontol. 2010, 45, 106-112. [CrossRef]

90. Quinn, L.S. Interleukin-15: A muscle-derived cytokine regulating fat-to-lean body composition. J. Anim. Sci. 2008, 86, E75-E83. [CrossRef]

91. Quinn, L.S.; Haugk, K.L.; Grabstein, K.H. Interleukin-15: A novel anabolic cytokine for skeletal muscle. Endocrinology 1995, 136, 3669-3672. [CrossRef]

92. Sharma, S.; Stolina, M.; Lin, Y.; Gardner, B.; Miller, P.W.; Kronenberg, M.; Dubinett, S.M. T cell-derived IL-10 promotes lung cancer growth by suppressing both T cell and APC function. J. Immunol. 1999, 163, 5020-5028. [PubMed]

93. Chen, W.; Jin, W.; Wahl, S.M. Engagement of cytotoxic T lymphocyte-associated antigen 4 (CTLA-4) induces transforming growth factor beta (TGF-beta) production by murine CD4(+) T cells. J. Exp. Med. 1998, 188, 1849-1857. [CrossRef] 
94. Sakaguchi, S.; Sakaguchi, N.; Shimizu, J.; Yamazaki, S.; Sakihama, T.; Itoh, M.; Kuniyasu, Y.; Nomura, T.; Toda, M.; Takahashi, T. Immunologic tolerance maintained by CD25+ CD4+ regulatory T cells: Their common role in controlling autoimmunity, tumor immunity, and transplantation tolerance. Immunol. Rev. 2001, 182, 18-32. [CrossRef] [PubMed]

95. Sinha, P.; Clements, V.K.; Ostrand-Rosenberg, S. Reduction of myeloid-derived suppressor cells and induction of M1 macrophages facilitate the rejection of established metastatic disease. J. Immunol. 2005, 174, 636-645. [CrossRef]

96. Keir, M.E.; Butte, M.J.; Freeman, G.J.; Sharpe, A.H. PD-1 and its ligands in tolerance and immunity. Annu. Rev. Immunol. 2008, 26, 677-704. [CrossRef] [PubMed]

97. Visconti, R.; Morra, F.; Guggino, G.; Celetti, A. The between now and then of lung cancer chemotherapy and immunotherapy. Int. J. Mol. Sci. 2017, 18, 1374. [CrossRef]

98. Desbois, M.; Le Vu, P.; Coutzac, C.; Marcheteau, E.; Beal, C.; Terme, M.; Gey, A.; Morisseau, S.; Teppaz, G.; Boselli, L.; et al. IL-15 trans-Signaling with the superagonist RLI promotes effector/memory CD8+ T cell responses and enhances antitumor activity of PD-1 antagonists. J. Immunol. 2016, 197, 168-178. [CrossRef]

99. Judge, S.J.; Darrow, M.A.; Thorpe, S.W.; Gingrich, A.A.; O’Donnell, E.F.; Bellini, A.R.; Sturgill, I.R.; Vick, L.V.; Dunai, C.; Stoffel, K.M.; et al. Analysis of tumor-infiltrating NK and T cells highlights IL-15 stimulation and TIGIT blockade as a combination immunotherapy strategy for soft tissue sarcomas. J. Immunother. Cancer 2020, 8. [CrossRef]

100. Zhang, M.; Yao, Z.; Dubois, S.; Ju, W.; Muller, J.R.; Waldmann, T.A. Interleukin-15 combined with an anti-CD40 antibody provides enhanced therapeutic efficacy for murine models of colon cancer. Proc. Natl. Acad. Sci. USA 2009, 106, 7513-7518. [CrossRef] [PubMed]

101. Bennett, S.R.; Carbone, F.R.; Karamalis, F.; Flavell, R.A.; Miller, J.F.; Heath, W.R. Help for cytotoxic-T-cell responses is mediated by CD40 signalling. Nature 1998, 393, 478-480. [CrossRef]

102. Ochoa, M.C.; Minute, L.; Lopez, A.; Perez-Ruiz, E.; Gomar, C.; Vasquez, M.; Inoges, S.; Etxeberria, I.; Rodriguez, I.; Garasa, S.; et al. Enhancement of antibody-dependent cellular cytotoxicity of cetuximab by a chimeric protein encompassing interleukin-15. Oncoimmunology 2018, 7, e1393597. [CrossRef]

103. Roberti, M.P.; Rocca, Y.S.; Amat, M.; Pampena, M.B.; Loza, J.; Colo, F.; Fabiano, V.; Loza, C.M.; Arriaga, J.M.; Bianchini, M.; et al. IL-2- or IL-15-activated NK cells enhance Cetuximab-mediated activity against triple-negative breast cancer in xenografts and in breast cancer patients. Breast Cancer Res. Treat. 2012, 136, 659-671. [CrossRef] [PubMed]

104. Moga, E.; Canto, E.; Vidal, S.; Juarez, C.; Sierra, J.; Briones, J. Interleukin-15 enhances rituximab-dependent cytotoxicity against chronic lymphocytic leukemia cells and overcomes transforming growth factor beta-mediated immunosuppression. Exp. Hematol. 2011, 39, 1064-1071. [CrossRef]

105. Zhang, M.; Wen, B.; Anton, O.M.; Yao, Z.; Dubois, S.; Ju, W.; Sato, N.; DiLillo, D.J.; Bamford, R.N.; Ravetch, J.V.; et al. IL-15 enhanced antibody-dependent cellular cytotoxicity mediated by NK cells and macrophages. Proc. Natl. Acad. Sci. USA 2018, 115, E10915-E10924. [CrossRef] [PubMed]

106. Liu, B.; Kong, L.; Han, K.; Hong, H.; Marcus, W.D.; Chen, X.; Jeng, E.K.; Alter, S.; Zhu, X.; Rubinstein, M.P.; et al. A novel fusion of ALT-803 (Interleukin (IL)-15 superagonist) with an antibody demonstrates antigen-specific antitumor responses. J. Biol. Chem. 2016, 291, 23869-23881. [CrossRef] [PubMed]

107. Felices, M.; Kodal, B.; Hinderlie, P.; Kaminski, M.F.; Cooley, S.; Weisdorf, D.J.; Vallera, D.A.; Miller, J.S.; Bachanova, V. Novel CD19-targeted TriKE restores NK cell function and proliferative capacity in CLL. Blood Adv. 2019, 3, 897-907. [CrossRef]

108. Schmohl, J.U.; Felices, M.; Taras, E.; Miller, J.S.; Vallera, D.A. Enhanced ADCC and NK cell activation of an anticarcinoma bispecific antibody by genetic insertion of a modified IL-15 cross-linker. Mol. Ther. 2016, 24, 1312-1322. [CrossRef] [PubMed]

109. Vallera, D.A.; Felices, M.; McElmurry, R.; McCullar, V.; Zhou, X.; Schmohl, J.U.; Zhang, B.; Lenvik, A.J.; Panoskaltsis-Mortari, A.; Verneris, M.R.; et al. IL15 Trispecific Killer Engagers (TriKE) make Natural Killer cells specific to CD33+ targets while also inducing persistence, in vivo expansion, and enhanced function. Clin. Cancer Res. 2016, 22, 3440-3450. [CrossRef] [PubMed]

110. Vincent, M.; Bessard, A.; Cochonneau, D.; Teppaz, G.; Sole, V.; Maillasson, M.; Birkle, S.; Garrigue-Antar, L.; Quemener, A.; Jacques, Y. Tumor targeting of the IL-15 superagonist RLI by an anti-GD2 antibody strongly enhances its antitumor potency. Int. J. Cancer 2013, 133, 757-765. [CrossRef]

111. Beha, N.; Harder, M.; Ring, S.; Kontermann, R.E.; Muller, D. IL15-based trifunctional antibody-fusion proteins with costimulatory TNF-superfamily ligands in the single-chain format for cancer immunotherapy. Mol. Cancer Ther. 2019, 18, 1278-1288. [CrossRef] [PubMed]

112. Kermer, V.; Baum, V.; Hornig, N.; Kontermann, R.E.; Muller, D. An antibody fusion protein for cancer immunotherapy mimicking IL-15 trans-presentation at the tumor site. Mol. Cancer Ther. 2012, 11, 1279-1288. [CrossRef]

113. Chapoval, A.I.; Fuller, J.A.; Kremlev, S.G.; Kamdar, S.J.; Evans, R. Combination chemotherapy and IL-15 administration induce permanent tumor regression in a mouse lung tumor model: NK and T cell-mediated effects antagonized by B cells. J. Immunol. 1998, 161, 6977-6984.

114. Evans, R.; Fuller, J.A.; Christianson, G.; Krupke, D.M.; Troutt, A.B. IL-15 mediates anti-tumor effects after cyclophosphamide injection of tumor-bearing mice and enhances adoptive immunotherapy: The potential role of NK cell subpopulations. Cell. Immunol. 1997, 179, 66-73. [CrossRef]

115. Wu, X.; Wu, Y.; Ye, H.; Yu, S.; He, C.; Chen, X. Interleukin-15 and cisplatin co-encapsulated thermosensitive polypeptide hydrogels for combined immuno-chemotherapy. J. Control Release 2017, 255, 81-93. [CrossRef] [PubMed] 
116. Sun, H.; Liu, D. IL-15/sIL-15Ralpha gene transfer suppresses Lewis lung cancer growth in the lungs, liver and kidneys. Cancer Gene Ther. 2016, 23, 54-60. [CrossRef] [PubMed]

117. Pilones, K.A.; Charpentier, M.; Garcia-Martinez, E.; Demaria, S. IL15 synergizes with radiotherapy to reprogram the tumor immune contexture through a dendritic cell connection. Oncoimmunology 2020, 9, 1790716. [CrossRef]

118. June, C.H.; O'Connor, R.S.; Kawalekar, O.U.; Ghassemi, S.; Milone, M.C. CAR T cell immunotherapy for human cancer. Science 2018, 359, 1361-1365. [CrossRef]

119. Berger, C.; Jensen, M.C.; Lansdorp, P.M.; Gough, M.; Elliott, C.; Riddell, S.R. Adoptive transfer of effector CD8+ T cells derived from central memory cells establishes persistent T cell memory in primates. J. Clin. Investig. 2008, 118, 294-305. [CrossRef]

120. Singh, N.; Perazzelli, J.; Grupp, S.A.; Barrett, D.M. Early memory phenotypes drive T cell proliferation in patients with pediatric malignancies. Sci. Transl. Med. 2016, 8, 320ra323. [CrossRef]

121. Gattinoni, L.; Lugli, E.; Ji, Y.; Pos, Z.; Paulos, C.M.; Quigley, M.F.; Almeida, J.R.; Gostick, E.; Yu, Z.; Carpenito, C.; et al. A human memory T cell subset with stem cell-like properties. Nat. Med. 2011, 17, 1290-1297. [CrossRef] [PubMed]

122. Alizadeh, D.; Wong, R.A.; Yang, X.; Wang, D.; Pecoraro, J.R.; Kuo, C.F.; Aguilar, B.; Qi, Y.; Ann, D.K.; Starr, R.; et al. IL15 enhances CAR-T cell antitumor activity by reducing mTORC1 activity and preserving their stem cell memory phenotype. Cancer Immunol. Res. 2019, 7, 759-772. [CrossRef] [PubMed]

123. Kochenderfer, J.N.; Somerville, R.P.T.; Lu, T.; Shi, V.; Bot, A.; Rossi, J.; Xue, A.; Goff, S.L.; Yang, J.C.; Sherry, R.M.; et al. Lymphoma remissions caused by anti-CD19 Chimeric Antigen Receptor T cells are associated with high serum Interleukin-15 levels. J. Clin. Oncol. 2017, 35, 1803-1813. [CrossRef] [PubMed]

124. Hurton, L.V.; Singh, H.; Najjar, A.M.; Switzer, K.C.; Mi, T.; Maiti, S.; Olivares, S.; Rabinovich, B.; Huls, H.; Forget, M.A.; et al. Tethered IL-15 augments antitumor activity and promotes a stem-cell memory subset in tumor-specific T cells. Proc. Natl. Acad. Sci. USA 2016, 113, E7788-E7797. [CrossRef]

125. Krenciute, G.; Prinzing, B.L.; Yi, Z.; Wu, M.F.; Liu, H.; Dotti, G.; Balyasnikova, I.V.; Gottschalk, S. Transgenic expression of IL15 improves antiglioma activity of IL13Ralpha2-CAR T cells but results in antigen loss variants. Cancer Immunol. Res. 2017, 5, 571-581. [CrossRef]

126. Lanitis, E.; Rota, G.; Kosti, P.; Ronet, C.; Spill, A.; Seijo, B.; Romero, P.; Dangaj, D.; Coukos, G.; Irving, M. Optimized gene engineering of murine CAR-T cells reveals the beneficial effects of IL-15 coexpression. J. Exp. Med. 2021, 218. [CrossRef]

127. Hoyos, V.; Savoldo, B.; Quintarelli, C.; Mahendravada, A.; Zhang, M.; Vera, J.; Heslop, H.E.; Rooney, C.M.; Brenner, M.K.; Dotti, G. Engineering CD19-specific T lymphocytes with interleukin-15 and a suicide gene to enhance their anti-lymphoma/leukemia effects and safety. Leukemia 2010, 24, 1160-1170. [CrossRef]

128. Liu, E.; Marin, D.; Banerjee, P.; Macapinlac, H.A.; Thompson, P.; Basar, R.; Nassif Kerbauy, L.; Overman, B.; Thall, P.; Kaplan, M.; et al. Use of CAR-transduced Natural Killer cells in CD19-Positive lymphoid tumors. N. Engl. J. Med. 2020, 382, 545-553. [CrossRef]

129. Liu, E.; Tong, Y.; Dotti, G.; Shaim, H.; Savoldo, B.; Mukherjee, M.; Orange, J.; Wan, X.; Lu, X.; Reynolds, A.; et al. Cord blood NK cells engineered to express IL-15 and a CD19-targeted CAR show long-term persistence and potent antitumor activity. Leukemia 2018, 32, 520-531. [CrossRef] [PubMed]

130. Franks, S.E.; Wolfson, B.; Hodge, J.W. Natural Born Killers: NK Cells in cancer therapy. Cancers 2020, 12, 2131. [CrossRef] [PubMed]

131. Wang, X.; Wu, Z.; Qiu, W.; Chen, P.; Xu, X.; Han, W. Programming CAR T cells to enhance anti-tumor efficacy through remodeling of the immune system. Front. Med. 2020, 14, 726-745. [CrossRef] [PubMed]

132. Zhang, S.; Zhao, J.; Bai, X.; Handley, M.; Shan, F. Biological effects of IL-15 on immune cells and its potential for the treatment of cancer. Int. Immunopharmacol. 2021, 91, 107318. [CrossRef] [PubMed]

133. Weninger, W.; Crowley, M.A.; Manjunath, N.; von Andrian, U.H. Migratory properties of naive, effector, and memory CD8(+) T cells. J. Exp. Med. 2001, 194, 953-966. [CrossRef] [PubMed]

134. Lenardo, M.J. Interleukin-2 programs mouse alpha beta T lymphocytes for apoptosis. Nature 1991, 353, 858-861. [CrossRef]

135. Klebanoff, C.A.; Gattinoni, L.; Palmer, D.C.; Muranski, P.; Ji, Y.; Hinrichs, C.S.; Borman, Z.A.; Kerkar, S.P.; Scott, C.D.; Finkelstein, S.E.; et al. Determinants of successful CD8+ T-cell adoptive immunotherapy for large established tumors in mice. Clin. Cancer Res. 2011, 17, 5343-5352. [CrossRef]

136. Ahmadzadeh, M.; Rosenberg, S.A. IL-2 administration increases CD4+ CD25(hi) Foxp3+ regulatory T cells in cancer patients. Blood 2006, 107, 2409-2414. [CrossRef]

137. Waldmann, T. The contrasting roles of IL-2 and IL-15 in the life and death of lymphocytes: Implications for the immunotherapy of rheumatological diseases. Arthritis Res. 2002, 4 (Suppl. 3), S161-S167. [CrossRef]

138. Pachella, L.A.; Madsen, L.T.; Dains, J.E. The toxicity and benefit of various dosing strategies for Interleukin-2 in metastatic melanoma and renal cell carcinoma. J. Adv. Pract. Oncol. 2015, 6, 212-221. [PubMed]

139. Boyman, O.; Kovar, M.; Rubinstein, M.P.; Surh, C.D.; Sprent, J. Selective stimulation of T cell subsets with antibody-cytokine immune complexes. Science 2006, 311, 1924-1927. [CrossRef]

140. Mitra, S.; Ring, A.M.; Amarnath, S.; Spangler, J.B.; Li, P.; Ju, W.; Fischer, S.; Oh, J.; Spolski, R.; Weiskopf, K.; et al. Interleukin-2 activity can be fine tuned with engineered receptor signaling clamps. Immunity 2015, 42, 826-838. [CrossRef]

141. Silva, D.A.; Yu, S.; Ulge, U.Y.; Spangler, J.B.; Jude, K.M.; Labao-Almeida, C.; Ali, L.R.; Quijano-Rubio, A.; Ruterbusch, M.; Leung, I.; et al. De novo design of potent and selective mimics of IL-2 and IL-15. Nature 2019, 565, 186-191. [CrossRef] [PubMed] 
142. Sockolosky, J.T.; Trotta, E.; Parisi, G.; Picton, L.; Su, L.L.; Le, A.C.; Chhabra, A.; Silveria, S.L.; George, B.M.; King, I.C.; et al. Selective targeting of engineered T cells using orthogonal IL-2 cytokine-receptor complexes. Science 2018, 359, 1037-1042. [CrossRef]

143. Su, E.W.; Moore, C.J.; Suriano, S.; Johnson, C.B.; Songalia, N.; Patterson, A.; Neitzke, D.J.; Andrijauskaite, K.; Garrett-Mayer, E.; Mehrotra, S.; et al. IL-2Ralpha mediates temporal regulation of IL-2 signaling and enhances immunotherapy. Sci. Transl. Med. 2015, 7, 311ra170. [CrossRef] [PubMed]

144. Conlon, K.C.; Lugli, E.; Welles, H.C.; Rosenberg, S.A.; Fojo, A.T.; Morris, J.C.; Fleisher, T.A.; Dubois, S.P.; Perera, L.P.; Stewart, D.M.; et al. Redistribution, hyperproliferation, activation of natural killer cells and CD8 T cells, and cytokine production during first-in-human clinical trial of recombinant human interleukin-15 in patients with cancer. J. Clin. Oncol. 2015, 33, 74-82. [CrossRef]

145. Miller, J.S.; Morishima, C.; McNeel, D.G.; Patel, M.R.; Kohrt, H.E.K.; Thompson, J.A.; Sondel, P.M.; Wakelee, H.A.; Disis, M.L.; Kaiser, J.C.; et al. A first-in-human Phase I study of subcutaneous outpatient recombinant human IL15 (rhIL15) in adults with advanced solid tumors. Clin. Cancer Res. 2018, 24, 1525-1535. [CrossRef] [PubMed]

146. Conlon, K.C.; Potter, E.L.; Pittaluga, S.; Lee, C.R.; Miljkovic, M.D.; Fleisher, T.A.; Dubois, S.; Bryant, B.R.; Petrus, M.; Perera, L.P.; et al. IL15 by continuous intravenous infusion to adult patients with solid tumors in a Phase I trial induced dramatic NK-cell subset expansion. Clin. Cancer Res. 2019, 25, 4945-4954. [CrossRef]

147. Cooley, S.; He, F.; Bachanova, V.; Vercellotti, G.M.; DeFor, T.E.; Curtsinger, J.M.; Robertson, P.; Grzywacz, B.; Conlon, K.C.; Waldmann, T.A.; et al. First-in-human trial of rhIL-15 and haploidentical natural killer cell therapy for advanced acute myeloid leukemia. Blood Adv. 2019, 3, 1970-1980. [CrossRef]

148. Romee, R.; Cooley, S.; Berrien-Elliott, M.M.; Westervelt, P.; Verneris, M.R.; Wagner, J.E.; Weisdorf, D.J.; Blazar, B.R.; Ustun, C.; DeFor, T.E.; et al. First-in-human Phase 1 clinical study of the IL-15 superagonist complex ALT-803 to treat relapse after transplantation. Blood 2018. [CrossRef]

149. Margolin, K.; Morishima, C.; Velcheti, V.; Miller, J.S.; Lee, S.M.; Silk, A.W.; Holtan, S.G.; Lacroix, A.M.; Fling, S.P.; Kaiser, J.C.; et al. Phase I Trial of ALT-803, A novel recombinant IL15 complex, in patients with advanced solid tumors. Clin. Cancer Res. 2018, 24, 5552-5561. [CrossRef]

150. Wrangle, J.M.; Velcheti, V.; Patel, M.R.; Garrett-Mayer, E.; Hill, E.G.; Ravenel, J.G.; Miller, J.S.; Farhad, M.; Anderton, K.; Lindsey, K.; et al. ALT-803, an IL-15 superagonist, in combination with nivolumab in patients with metastatic non-small cell lung cancer: A non-randomised, open-label, phase 1b trial. Lancet Oncol. 2018, 19, 694-704. [CrossRef] 